Portland State University

PDXScholar

1990

\title{
A Survey of Diplomatic and Commercial Relations Between the United States and Oman in Zanzibar, 1828-1856
}

Mohammed Al-Mukadam

Portland State University

Follow this and additional works at: https://pdxscholar.library.pdx.edu/open_access_etds

Part of the African History Commons, and the United States History Commons Let us know how access to this document benefits you.

Recommended Citation

Al-Mukadam, Mohammed, "A Survey of Diplomatic and Commercial Relations Between the United States and Oman in Zanzibar, 1828-1856" (1990). Dissertations and Theses. Paper 3952.

https://doi.org/10.15760/etd.5836

This Thesis is brought to you for free and open access. It has been accepted for inclusion in Dissertations and Theses by an authorized administrator of PDXScholar. Please contact us if we can make this document more accessible: pdxscholar@pdx.edu. 
AN ABSTRACT OF THE THESIS OF Mohammed Al-Mukadam for the degree of Master of Arts in History, presented May, 1990.

Title: A Survey of Diplomatic and Commercial Relations Between the United States and Oman in Zanzibar, 1828-1856.

APPROVED BY THE MEMBERS OF THE THESIS COMMITTEE:

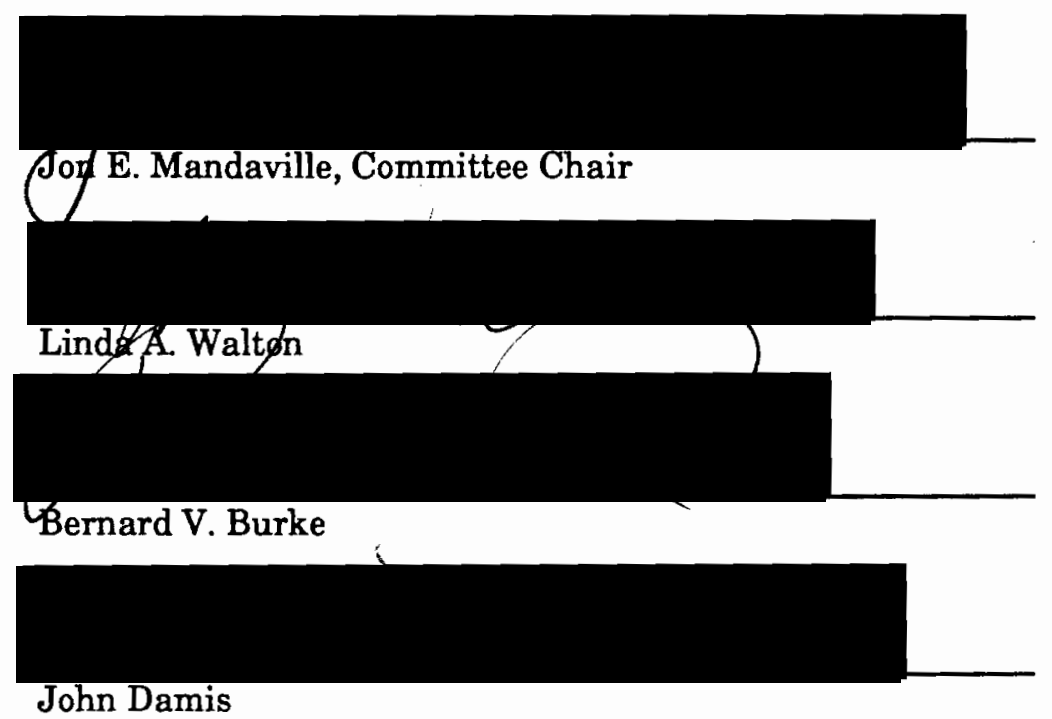

Informal relations between American merchant traders and the Sultanate of Oman in the port of Zanzibar began with the landing of the first American merchants about 1828. At the same approximate time, Sultan Said bin Sultan moved his official residence from Muscat, Oman, to Zanzibar, underlining the importance of Zanzibar to the administration of his territories on the East African coast. Relations were formalized by the Treaty of 1833 between the United States and Oman, and the U.S. established a consular mission in Zanzibar in 1837 and in Muscat in 1838. 
The growth of the Omani Empire under Sultan Said expanded and prospered during the period examined in the present research (1828-1856). Oman's growth and prosperity, resulting primarily from its possession of Zanzibar and ports on the East African coast, roughly parallels the expansion and prosperity of the Zanzibar trade to American merchant traders. After Said's death, the Omani Empire was divided in a bitter succession battle (abetted by the British, who enjoyed military dominance in the region), and this point marked the beginning of the decline of the Oman as a regional economic and political power.

The present study surveys these two parallel developments over the critical 28-year reign of Sultan Said. The survey finds that, as with much economic development in the "third world" in the nineteenth century, Oman's enormous growth and prosperity during this period was directly linked to the growth and prosperity of commercial interests of a "developed" Western nation (in Oman's case, the United States). The study found that political developments between the two countries followed, and were informed and directed by, commercial developments. America's first three consuls to the Sultanate of Oman in Zanzibar were New England merchant traders more focused on their own commercial interests than on political concerns. That both parties (American traders and the Omani government) ultimately prospered is testimony to the complementary nature of their respective economic goals and foreign policy objectives. 


\section{A SURVEY OF DIPLOMATIC AND COMMERCIAL RELATIONS BETWEEN THE UNITED STATES AND OMAN IN ZANZIBAR, 1828-1856}

by

MOHAMMED AL-MUKADAM

A thesis submitted in partial fulfillment of the requirements for the degree of

MASTER OF ARTS

in

HISTORY

Portland State University

1990 
TO THE OFFICE OF GRADUATE STUDIES:

The members of the Committee approve the thesis of Mohammed AlMukadam presented May, 1990.

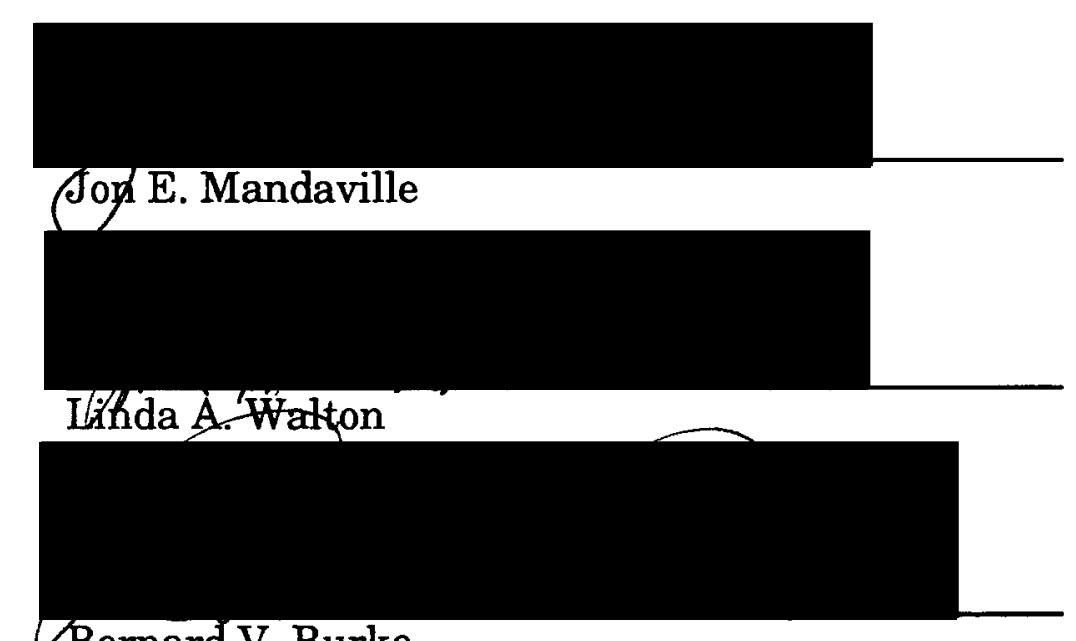

Bernard V. Burke

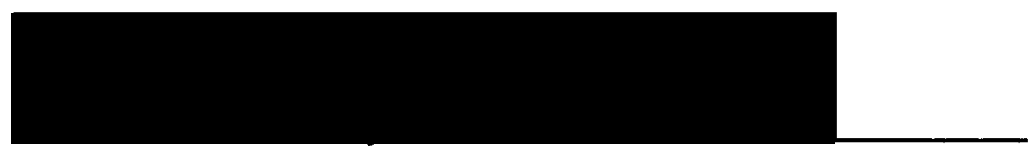

John Damis

APPROVED:

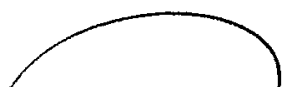

Bernard V. Burke, Chair, Department of History

C. William Savery, Interim Vice Provost fer Graduate Studies and Research 


\section{ACKNOWLEDGEMENTS}

I wish to acknowledge my debt and gratitude to several people who have assisted me at various stages of the research and writing of this thesis. I wish to thank officials of Sultan Qaboos University for sending me to complete my graduate study at Portland State University. I offer most special thanks to my thesis advisor, Dr. J.E. Mandaville, for many years of profitable instruction and discussion. During the years of study and through the preparation of this thesis, I always found him helpful, patient, and kind. I also wish to thank Dr. Norman Bennett, professor of history at Boston University and editor of the International Journal of African Historical Studies. His kindness, hospitality and his useful suggestions have enhanced the quality of the present research effort. I will never forget his invitation to dine, despite the flood then besetting Boston. Dr. Herman Eilts, Director of The Center for International Relations at Boston University and most prominent expert on Omani-American relations was most helpful with his suggestions and kindness. He allowed me to read his new book on Edmund Roberts.

I wish also to thank Sayyid Faysal bin Ali-Said, the Minister of National Heritage and Culture in Oman, for allowing me access to the Zanzibar archives at his ministry, and Mrs. Zubaida Juwad for her assistance in the archive. Also due my gratitute is the entire staff of librarians at the Cultural Foundation in Abu Dhabi, United Arab Emirates, and specifically Shaikh Ahmad bin Said Al-Hamad, Assistant Director of the Center for 
Documentation and Research, for allowing me to make free copies of documents from the American and European archives. He was both kind and generous with his time and resources.

In Salem, Massachusetts, I wish to thank John Koza, librarian at the Peabody Museum, and the entire staff at the Essex Institute for their generous assistance and kindness. Also due thanks are the librarians and staff members at the Portland State University library. I also wish to thank Nick Gattuccio, who edited and typed this thesis, for his patience with my hand writing. My gratitude also goes to my dissertation committee members, whose time and care with successive drafts of the present thesis had done much to improve its quality and merit.

And finally, my thanks go to my wife, Zamzam, for her encouragement and patience during the long hours of work on this thesis. 


\section{TABLE OF CONTENTS}

PAGE

ACKNOWLEDGEMENTS ................................................................... ii

LIST OF TABLES.......................................................................... vii

LIST OF FIGURES ............................................................................ viii

\section{CHAPTER}

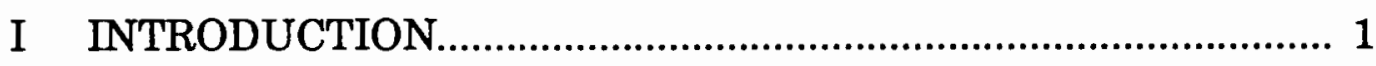

II THE ROBERTS MISSION, 1828-1836 .......................................... 9

Roberts' First Voyage to Zanzibar............................................ 13

Edmund Roberts and the Diplomatic Initiative................... 15

The British Backlash ......................................................... 19

Roberts' Third Voyage............................................................. 21

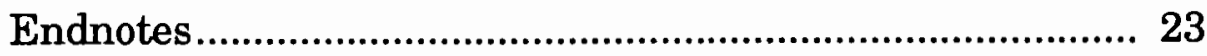

III THE WATERS YEARS, 1837-1845.............................................. 27

Said bin Sultan Consolidates Power in East Africa............. 27

The Capital is Moved to Zanzibar........................................ 29

Richard P. Waters Arrives in Zanzibar................................ 30

The Waters-Sewji Monopoly................................................ 34

British Consul Hamerton ........................................................ 37

Collapse of the American Monopoly in Zanzibar.................. 41

The Waters Legacy, in Retrospect ........................................ 43 


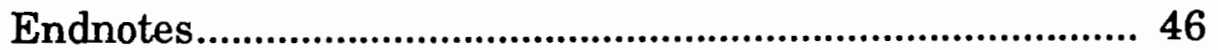

IV THE CHARLES WARD AND WILLIAM MCMULLAN

YEARS, 1845-1856...................................................... 50

The Ann Perry Affair.................................................... 51

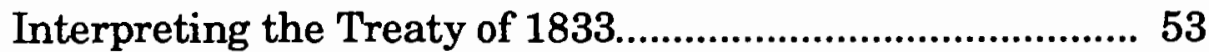

The Status of Indian Nationals...................................... 55

The Flag Dispute and Ward's Final Years........................ 57

The William McMullan Years and the Death of Said, 1852-1856..................................................... 59

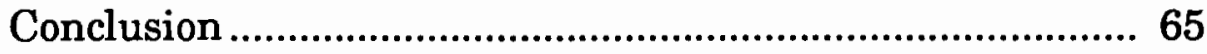

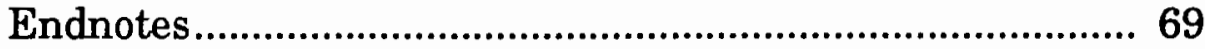

SELECTED BIBLIOGRAPHY..................................................... 72 


\section{LIST OF TABLES}

I Annual American Exports to Zanzibar, 1838-1854 


\section{LIST OF FIGURES}

FIGURE

PAGE

1. Map of Western Indian Ocean showing Omani territories and areas of influence, circa 1850. 6

2. Map of Western Indian Ocean showing primary settlements and topographical regions. 7

3. Map of East African coast, showing primary settlements and geographical features. 8 


\section{CHAPTER I}

\section{INTRODUCTION}

Diplomatic and economic relations between the United States and the Sultanate of Oman date to the early nineteenth century, when American merchants first developed an interest in the Zanzibar trade. Zanzibar, at that time, was part of the realm of the Sultan of Oman, as was a large portion of the coast of East Africa. That the early history of the development of diplomatic relations between the U.S. and Oman so closely parallels the development of economic relations goes to the heart of the findings of the present research effort. In fact, it was the growth of relations between Omani officials and American merchant traders that first necessitated the creation of formal diplomatic relations between the two countries. It was in the natural course of events, then, that America's diplomatic envoys to Oman in the nineteenth century were merchant traders.

There is a long history of contact between the Arab peoples and the populations of Zanzibar and East Africa, with the Omanis being the major group of Arabs settled in the areas by the year A.D. 1000. In 1503 the Portuguese occupied Mombasa and other East African coastal sites as part of their expansionist activity in the Indian Ocean region. They occupied Muscat in 1508 and remained there until 1650, when the rising Yaaruba Dynasty of Oman ousted them. The Yaaruba carried their war against the Portuguese to their settlements in East Africa and the Indian Ocean.

By 1698 the Yaaruba controlled the entire East African coast. In 1744, 
Ahmed bin Said, a challenger of Yaarubi leadership in Oman, was elected Imam after successfully fighting off a Persian invasion of Oman. His ascendancy culminated in the founding of the Al-Busaid dynasty, which has continued its rule in Oman to the present day.

After Imam Ahmed, the greatest of the early Al-Busaid rulers was Sayyid Said bin Sultan, who ruled Oman from 1804 to 1856 and was responsible for Oman's expansion and political influence through the Gulf region and extending over East Africa. Sayyid Said bin Sultan, ruler of Muscat, Zanzibar, and its dependencies in East African arrived in Zanzibar for the first time in 1828. At the time he was involved in civil strife with the Mazrui clan of Mombassa. In Zanzibar he met Captain Edmund Roberts, an American trader. Given his internal difficulties as well as his desire to expand his realm in the Gulf region, Sayyid Said seized the opportunity to suggest to Roberts that the Americans negotiate a commercial treaty with Oman. His hopes included the possibility of future American military assistance, although this was not to come about. Regardless, Roberts returned to the United States and began a lobbying effort through Senator Levy Woodbury, a family acquaintance, which resulted in President Jackson agreeing to send a special mission to Muscat, Oman and other Far Eastern ports to negotiate treaties for the protection of American trade in those regions. Furthermore, he appointed Edmund Roberts to the position of Special Agent with the power to negotiate on behalf of the U.S. Government for treaties with Muscat, Siam, and Cochin-China.

On September 21, 1833, Roberts and Sayyid Said signed the first treaty ever between the United States and an Eastern Arabian state. The 
treaty was ratified by the U.S. Congress in June, 1834, and ratified treaties were formally exchanged on September 30,1835 . At this point diplomatic and commercial relations between the United States and Oman were officially opened. This Treaty of 1833 became a model for later commercial treaties between Oman and Britain, France, and the Hanseatic cities of Germany.

Sayyid Said soon consolidated his economic and political power in East Africa. In 1837 he defeated the Mazrui of Mombassa and moved his realm's capital from Muscat to Zanzibar, placing the heart of his commercial empire on the threshold of East Africa. That same year, Richard P. Waters, America's first Consul to the Sultanate of Oman, and the first foreign emissary to take up a posting in the Sultan's new capital, arrived in Zanzibar to establish the U.S. mission. The following year Henry Marshall took up a similar position in the former Omani capital of Muscat. Thus, OmaniAmerican relations were cemented, and trade between the two countries began to grow.

Richard P. Waters was a merchant trader, and his tenure in Zanzibar reflected his orientation. He established cordial relations with the Sultan and formed an alliance with Jairam Sewji, the master of the custom house in Zanzibar. Over the next few years Waters and Sewji formed a virtual monopoly over trade through Zanzibar. The arrangement was quite profitable for both, and Waters' trading company enjoyed a profitable inside track in the Zanzibar trade. The arrangement was certainly unethical, if not completely illegal, by today's standards of diplomatic protocol, but at that time the guidelines were less well defined. However, their arrangement began to falter after 1841, when the British, who were the dominant military power in the 
region at the time, posted their first British Consul to Zanzibar. This was a man named Atkins Hamerton, and when he arrived and noted the strength of the economic and political influence gained by the Americans in the space of just a few years set himself to the task of undermining American influence while at the same time protecting British commercial and political interests and working toward suppressing the East African slave trade. Compounding the work of Hamerton, envoys from other European countries, most notably the French, also entered the market, as did competing American firms. The end result was that the Waters-Sewji monopoly crumbled under the weight of competing interests. In 1844 Waters left Zanzibar and resigned his post the following year.

America's second consul to Zanzibar was Charles Ward, who arrived in 1846. His years in Zanzibar were marked with controversies, some of them substantial, others quite trivial (including a heated dispute over the Sultan's failure to offer a formal salute to the American flag on the Fourth of July). In fact, Ward succeeded in undoing a great deal of the foundations that Waters had laid, and his tenure culminated in the breaking off of diplomatic relations. This damage was repaired by John Aulick, who was dispatched by the State Department in 1851, but a significant amount of the goodwill between the two countries had been damaged. Ward resigned his position in 1852.

The third American Consul to Zanzibar was William McMullan (18521856), who succeeded in improving Omani-American relations, regaining much of the ground that Ward had lost. During his tenure trade between Oman and the United States flourished. This was a time when Sayyid Said 
was once more occupied with civil difficulties over the Wahabbis in Oman and with a Persian threat over Bander Abbas. The period (and the scope of the present research) concludes with the death of Sayyid Said in 1856.

The scope of this thesis, then, encompasses commercial and diplomatic contact between the Sultanate of Oman and the United States, from the time of the earliest, informal commercial contact, through the development of formal treaties, and culminating with the death of Sayyid Said and the subsequent breakup of the Omani Empire. The thesis will document the commercial origins and economic rationale for the formal diplomatic ties that developed between the two countries.

Following are Figures 1, 2, and 3, which present maps of the regions under discussion in the present thesis 


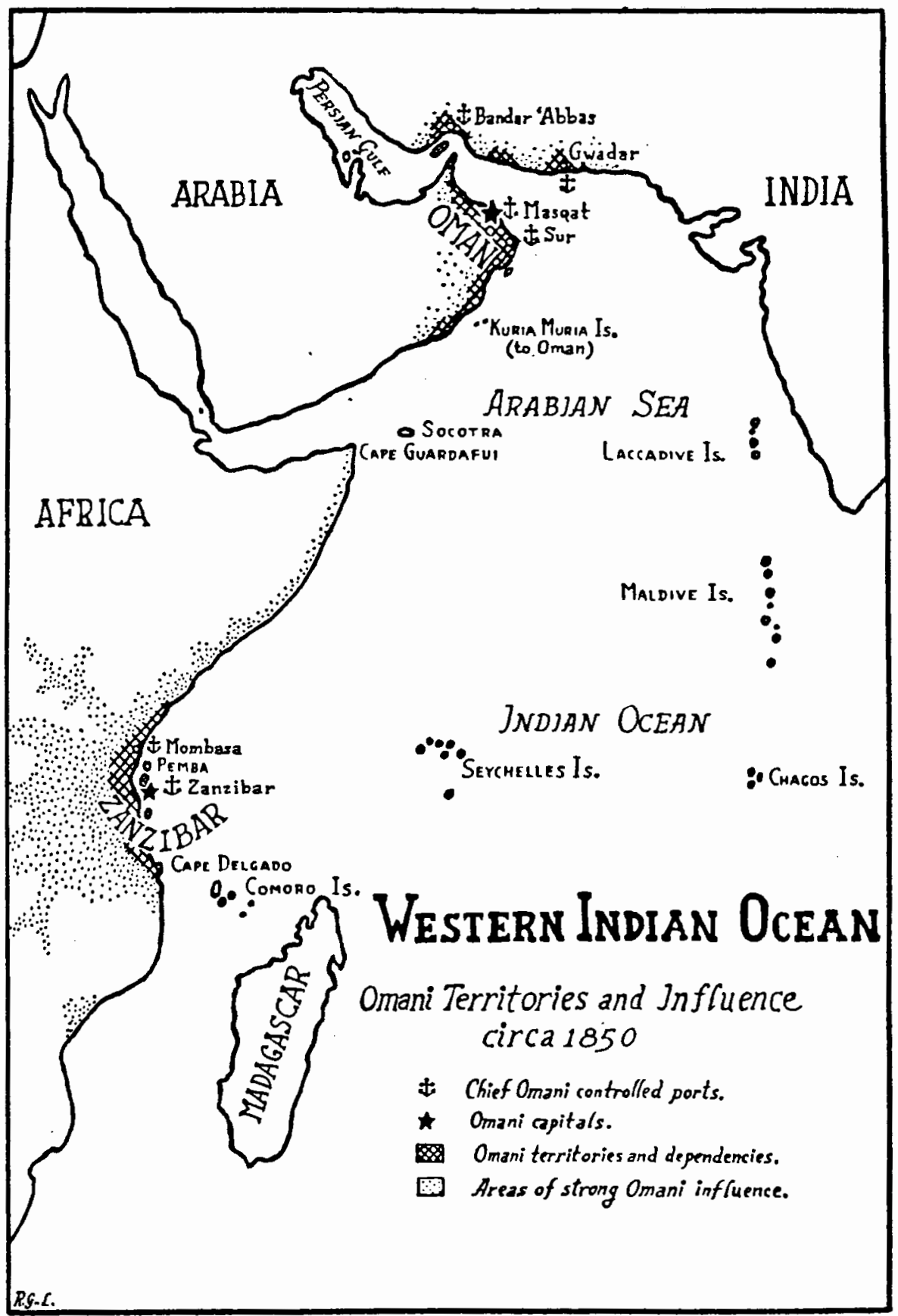

Figure 1. Map of Western Indian Ocean showing Omani territories and areas of influence, circa 1850. (Source: Landen, Oman Since 1856, p. 73.) 


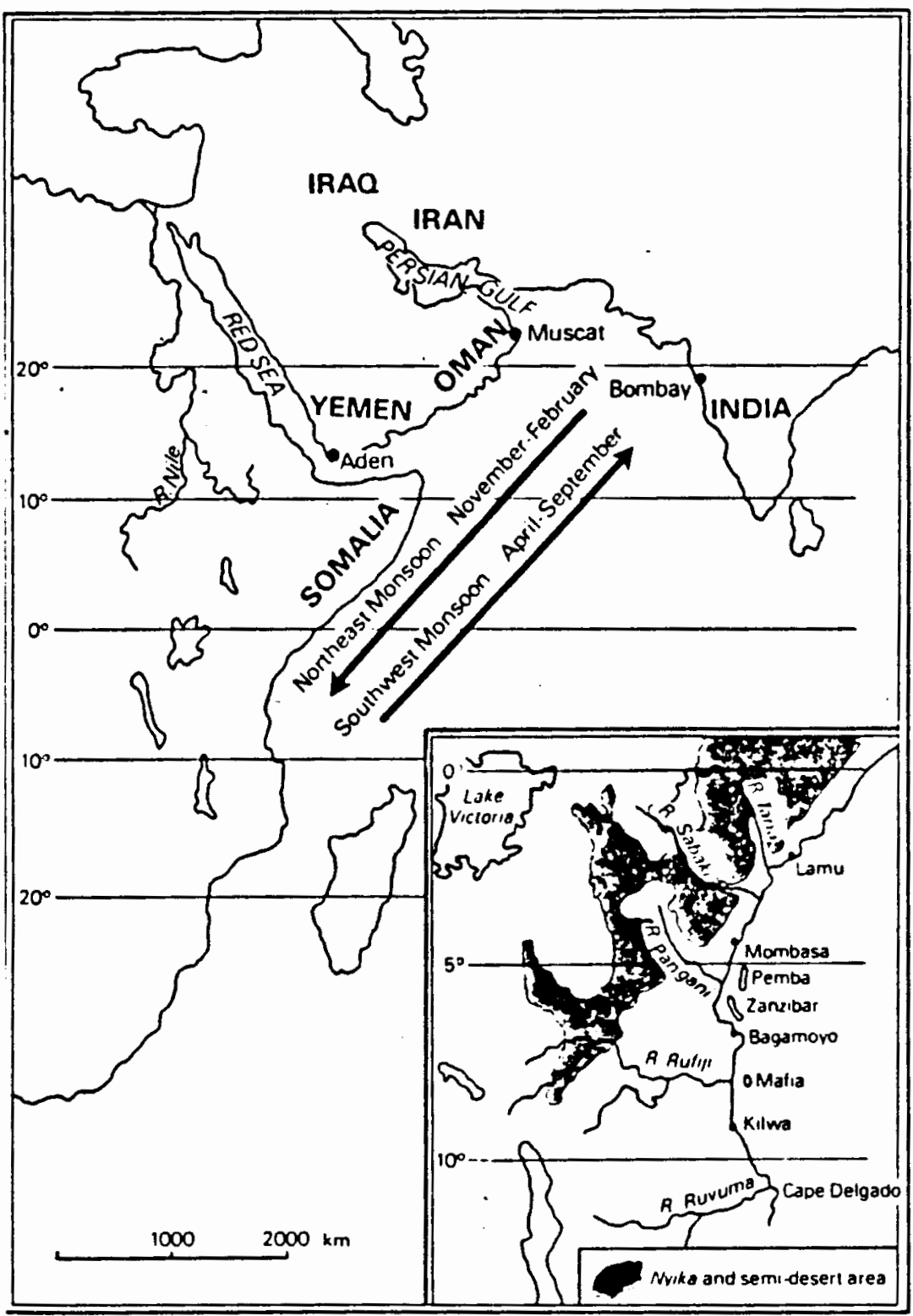

Figure 2. Map of Western Indian Ocean showing primary settlements and topographical regions. (Source: Sheriff, Slaves, Spices and Ivory in Zanzibar, p. 9.) 


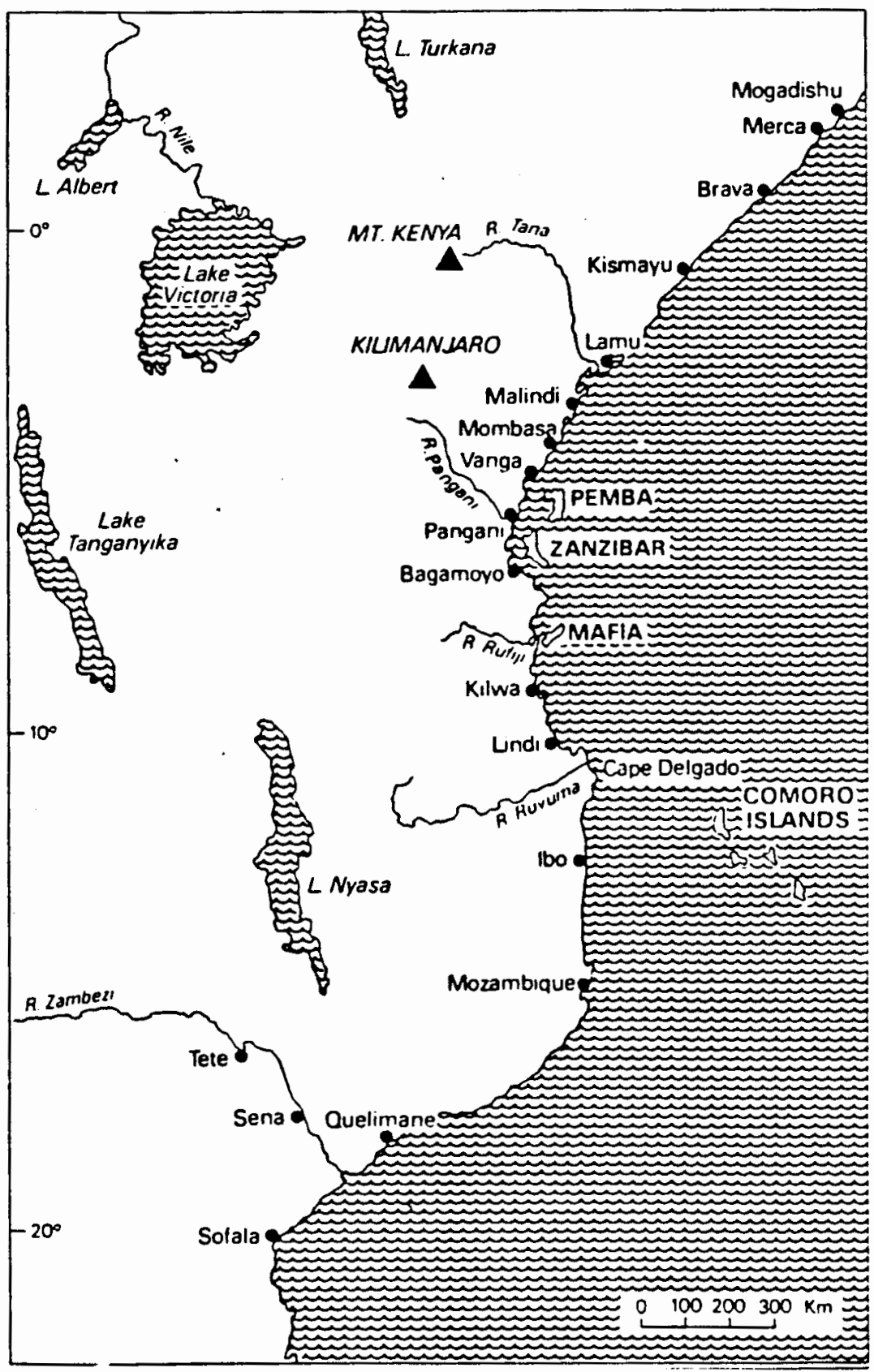

Figure 3. Map of East African coast, showing primary settlements and geographical features. (Source: Sheriff, Slaves, Spices and Ivory in Zanzibar, p. 25.) 


\section{CHAPTER II}

\section{THE ROBERTS MISSION, 1828-1836}

Commercial contact between America and Oman existed well before the Treaty of 1833 , as both countries had long standing maritime traditions. For centuries Omani vessels had been calling at ports in East Africa, India, the East Indies, and in China. Although a young nation, the United States in the nineteenth century had a strong merchant fleet. American vessels from New York, Boston and Salem sailed around both Cape Horn and the Cape of Good Hope, touching the great ports on all the seas, including those of the Pacific Islands, the East Indies, China, East Africa, and most of the other primary global ports. Among these was Muscat, Oman.

Records indicate that the first American vessel to visit Muscat was the Boston brig, Rambler, which touched port in Muscat during the presidency of George Washington, in 1790.1 Five years later, in 1795, Charles Derby reached Muscat in the brig Cadet out of Salem. Derby purchased a cargo of coffee in what became the beginning of a lucrative trade for Salem merchants in Muscat. ${ }^{2}$ American merchant traders were able to bring to the Omanis a wide variety of goods that were in great demand in Zanzibar and East Africa, among them cotton, cloth, guns and powder, household goods such as crockery, glassware, chairs, and domestic goods like soap, white sugar, and flour. Also traded were American goods that were useful in their own trade with the African interior, including things like beads, brass wire, and 
miscellaneous kinds of hardware. Most highly valued of all, however, was American cotton cloth. It was during this period that the word "merikani" passed into the language of the region, and is used to this day to denote American cloth. It was far superior to British and Indian cloth and was in great demand, giving American traders from New England (the textile capital of the U.S.) a great trading advantage.

In exchange, the Omanis traded cloves, ivory, dates, animal hides, palm oil, ginger, and gum-copal. The hides were essential to an expanding shoe manufacturing industry in New England. Palm oil was used in the manufacture of soap as well as being in demand for lubricating industrial machinery prior to the rise of mineral oil. Gum-copal was the base for fine varnishes and lacquers in the making of furniture.

Following in Table I is a summary of American exports to Zanzibar in contemporary dollars. 
TABLE I

ANNUAL AMERICAN EXPORTS TO ZANZIBAR, 1838-1854

\begin{tabular}{|c|c|c|c|}
\hline \multicolumn{2}{|c|}{ Year/\$ } & \multicolumn{2}{c|}{ Year/\$ } \\
\hline 1838 & $\$ 96,923$ & 1847 & incomplete \\
\hline 1839 & 113,141 & 1848 & 214,757 \\
\hline 1840 & 101,922 & 1849 & 380,000 \\
\hline 1841 & 218,712 & 1850 & 275,242 \\
\hline 1842 & 196,982 & 1851 & unavailable \\
\hline 1843 & 179,372 & 1852 & 471,200 \\
\hline 1844 & incomplete & 1853 & 375,675 \\
\hline 1845 & 240,396 & 1854 & 495,806 \\
\hline 1846 & 186,675 & & \\
\hline
\end{tabular}

Source: C.S. Nicholls, The Swahili Coast p. 332.

It can be seen that the value of American exports to Zanzibar rose steadily, though intermittantly, throughout the seventeen-year period. Although not America's leading trading partner by any means, Zanzibar still ranked as a significant trading partner. Comparable figures for that period of America's imports from other countries shows that in 1845, for example, America imported $\$ 1$ million from Mexico, \$3 million from Germany, and \$7 million from China. Total world imports in that year were $\$ 113$ million.

American trade with Omani and East African ports continued smoothly for a quarter century, until political unrest in the Arabian Gulf and the Qawasim challenge to British power in the region disrupted Muscat's 
trading position. ${ }^{3}$ However, American vessels continued to visit East African ports, with twelve American vessels visiting East African ports in 18044, and trade continued growing until it was abruptly halted by President Jefferson's shipping embargo that was in place from 1807 to 1809. The intention of the embargo was to coerce British and French recognition of American rights, but the unintended result was to put the majority of the American merchant fleet out of commission. In addition, the Napoleonic War and the War of 1812 both inhibited American commercial shipping, resulting in serious setbacks to America's commercial position in the Indian Ocean. Smaller ports like Salem never fully recovered; for example, of Salem's two hundred registered vessels in 1812 , only fifty-seven survived to recommence foreign trade at war's end. 5

Upon completion of the War of 1812 with the signing of the peace treaty in 1815, American vessels began returning to maritime activities. However, Salem merchants could no longer compete with New York and Boston for new Western markets, and contented themselves to continue trade with East Africa, the East Indies, Oman, and other Eastern ports. Thus, it was Salem merchants who eventually became the leading American traders with East African and Indian Ocean ports. One example is that of N.L. Roger, one of the early Salem traders. He reported direct contacts with the islands of Mauritius and Reunion as early as 1804,6 and further claimed to have opened the Madagascar and Zanzibar trades. ${ }^{7}$ However, the date of the earliest visit of an American vessel at the port of Zanzibar is difficult to establish with certainty, since ship's records rarely record all ports visited on a given trading cruise, since ship captains and merchants were reluctant to disclose potential lucrative markets. However, the first recorded visit of an American trading 
vessel to the port of Zanzibar was in 1826, when the brig Ann visited the port. 8 On March 1, 1826, the brig Virginia mastered by one Captain Goodridge reached Zanzibar. His return trip is the first known to have sailed directly to Salem from Zanzibar. Captain Goodridge made the voyage in ninety-five days, arriving in Salem on June 18, 1826. Captain Goodridge noted that seven American vessels had reached port at Zanzibar. ${ }^{9}$

\section{ROBERTS' FIRST VOYAGE TO ZANZIBAR}

The most significant early voyage to Zanzibar from the point of view of Omani-American relations was that of the ship Mary Ann, sailing from New Bedford, New Hampshire, with one Edmund Roberts as captain. He sailed with a cargo consigned to him with the hope of profitable trade in the new port of Zanzibar, which he'd learned of through an earlier voyage to Bombay.

Roberts had been orphaned at sixteen and raised by his uncle, Captain Joshua Roberts, who had established a mercantile shipping business in Buenos Aires. Edmund was eventually placed in charge of his uncle's business and in 1807 became sole proprietor upon his uncle's death. 10 However, this was the period of President Jefferson's embargo on foreign trade, which was followed by the disastrous period of the War of 1812 . Roberts lost a fortune and struggled for years to recoup losses and preserve his interest in his uncle's business. In 1827 he borrowed a sum of money, chartered the brig Mary Ann, acquired a cargo on consignment, and in October of that year arrived in Zanzibar to attempt to sell his cargo.11 Roberts encountered considerable obstacles to trade in Zanzibar, however. Prominent among these was that he was forced to conduct business 
through the agents of Sayyid Said Al-Busaid, ruler of Muscat, Zanzibar and its dependencies. In Zanzibar, all visiting merchants were at the mercy of his agents. They were subject to delays in payment, to the substitution of undesirable goods for those originally contracted, and to inflated prices. Additionally, commissions had to be paid to agents not actually hired by the merchants; taxes of seven and a half percent had to be paid on exports and imports; and a $\$ 100.00$ fee had to be paid for trading rights. 12 At the same time, Roberts was of the opinion that the British were unfairly allowed to deal freely in the Zanzibar market, since they were Said's primary ally.

In January, 1828, Said bin Sultan arrived in Zanzibar from Muscat for his first visit to Zanzibar, the island that was soon to become the co-capital of his realm and his principal place of residence. 13 Roberts sought an immediate audience with Said in order to protest the treatment given American traders by his agents in Zanzibar. Roberts took the liberty of representing himself as an American official (he had once been named American Consul to Demerara, British Guyana, a post which he did not take). ${ }^{14}$ Regardless, the deception succeeded. Sayyid Said welcomed the selfappointed American official and granted him a number of audiences wherein Roberts had the opportunity to express his and other American traders' grievances. Roberts asked that American traders be given equal footing with the British in the Sultan's ports. Roberts went so far as to suggest that the Sultan's best political interests lay with the Americans, who desired only the pursuit of legitimate trade and had none of the secondary political and territorial aspirations in the region that one found in the British and French. 15 
For his part, Sayyid Said saw great advantages in a strong commercial relationship with the United States. Not only would the Americans lighten his dependence on his British allies, but it might even be useful playing them off against the British should the need one day arise. 16 Accordingly, he suggested to Roberts the feasibility of a formal treaty with the United States, and expressed his desire to receive an American mission for the purpose of negotiating and signing such a treaty. Additionally, he asked that Roberts inform his government of Said's appeal for military equipment that he might use to drive the Portuguese out of Mozambique as well as control the Mazrui family in Mombasa and old enemies in the Gulf. He promised to keep this request secret from the English. 17

Said bin Sultan's desire to place diplomatic and commercial relations with the United States on an official treaty basis was based on both political and economic reasoning. Said faced significant challenges to his power base in Oman, East Africa and the Arabian Gulf. Furthermore, his allies the British were increasing their power in the Indian Ocean. The Americans, on the other hand, were seen as the new power in the area, and one without territorial ambitions. Consequently, Said felt that he could deal with Americans freely without undue fear of compromising his independence.

\section{EDMUND ROBERTS AND THE DIPLOMATIC INITIATIVE}

Upon his return to the United States in May, 1828, Roberts immediately urged action on the part of the American government to support American trade in Zanzibar and Muscat. 18 Roberts' efforts began with intensive lobbying of the chairman of the powerful Senate Commerce 
Committee, Senator Levi Woodbury, who was a strong supporter of New England's commercial expansion. A fellow native of New Hampshire, and related to Roberts through marriage, Woodbury showed great interest in Roberts' position. In response to Woodbury's interest, Roberts prepared a lengthy communication in which he related an account of his most interesting conversations with Said as well as summarizing Said's political position and the range of his power through the Gulf and East Africa. 19 Unfortunately for Roberts, however, despite Woodbury's interest and influence, the senator's efforts came to nothing. Said's territories were unknown to most Americans, after all, and the nation had just taken a significant new turn toward domestic issues and westward expansion under President Andrew Jackson. 20 Two years later, however, in May, 1831, Senator Woodbury became President Jackson's Secretary of the Navy. In this capacity, Woodbury was finally able to persuade Jackson to send a special agent to Muscat and the Far East. At the same time, President Jackson received a cordial letter from Sayyid Said, delivered through one Captain Burnham, expressing his desire to formulate a commercial treaty between their two countries. ${ }^{21} \mathrm{Through}$ Woodbury's influence, Roberts was invited to Washington and the State Department named him Special Agent to negotiate treaties with Siam, Cochin-China and Muscat. In his special instructions to Roberts, Secretary of State Edward Livingstone informed him that his mission was to be kept secret from the English, Dutch, and French, whose interests might be to thwart the objectives the president had in view. 22 Roberts was further informed that the American government had no political or territorial ambitions in these regions. In the Secretary of State's words: "We never make 
conquests or ask any nation to let us establish ourselves in their country, as the English, the French and Dutch. ${ }^{23}$

In March, 1832, Roberts sailed for the Far East aboard the U.S. sloop of war, Peacock. His primary mission was to meet, confer with, and negotiate treaties with the rulers of Siam, Cochin-China, and Muscat. Roberts was listed on the ship's manifest as the captain's clerk in order to maintain the secrecy of the mission. 24 Roberts' mission to Cochin-China failed because he refused to kowtow to the ruler and was ultimately denied an audience. In Siam, Roberts succeeded in negotiating a trade agreement. Following diplomatic efforts in Cochin-China and Siam, Roberts at last arrived in Muscat on September 18, 1833.25

Said bin Sultan received Roberts like an old friend. He held a warm reception and Roberts delivered a letter from President Jackson. During their negotiations, Roberts pointed out that contrary to the English, French, and Dutch, the American government's goal was merely a mutual commercial treaty with Said's dominions. However, Said then made a surprising proposal: he offered the Americans a commercial establishment anywhere in his territories if they would agree to help him conquer Mombasa. ${ }^{26}$ Roberts refused Said's proposal outright, explaining that the U.S. was only interested in forming a commercial treaty, not in becoming involved in regional political conflicts. Said relented and the first Omani-American treaty, "The Treaty of Amity and Commerce," was signed on September 21, 1833.27

This Treaty of 1833 gave the Americans considerable trading advantage. American traders were to be afforded "most favored nation" status and be allowed to trade freely in all ports in the Sultan's realm, paying no 
fees beyond a five percent import tax on all goods landed in the Sultan's ports. Even common pilotage fees were dropped for American traders. This provision for free American access to all of the Sultan's ports was soon to cause considerable difficulties for Said when other nations were to press him for access to areas on the mainland coast opposite Zanzibar. These coastal ports were presently closed to all but American traders. Furthermore, the U.S. was given broad rights in the establishment of a consulate; its properties and the person of its occupant were to be inviolable, and only a complaint directly to Washington could result in his removal. In addition, the American Consul was given complete power over all disputes concerning Americans and their property. Unfortunately, however, no mention was made of disputes between Americans and Omanis in Said's dominions, an oversight that would cause much trouble between Said and the second American Consul in Zanzibar some years later. In exchange for these concessions, Said bin Sultan was given the rights of most favored nation for any vessel he might send to the United States. The only restriction placed upon his trade was a temporary one: that powder, muskets, and shot could only be sold in Zanzibar, and only to the government. This clause was a concession to Said, who at the time was embroiled in a rebellion in Mombasa orchestrated by the Mazrui family. 28

Both Sayyid Said and Roberts were quite pleased and satisfied with the conclusion of the treaty. For his part, Said was happy that he was treated as an equal by President Jackson. Said viewed the treaty as an opportunity to form a new political friendship that would eventually enhance his own prestige as well as bolstering his economy through trade. On the other hand, 
Roberts was quite pleased that his first diplomatic foray had concluded with such pleasing results, having succeeded in obtaining for American traders free access to the entirety of the Sultan's dominions. This was quite a different state of affairs from when he first arrived in Zanzibar aboard the brig Mary Ann just six years before.

\section{THE BRITISH BACKLASH}

If Roberts and Sayyid Said were pleased with themselves over their treaty, the British surely were not. They had become accustomed to American vessels throughout the Pacific, Southern Asia, and the Indian Ocean, and they had developed a delicate balance of power with the other European colonial powers--the French in Cochin-China, the Portuguese in Mozambique, and the Dutch in Batavia--but this new development of a U.S. warship with a diplomatic emissary expanding American interests in the region was too much. 29 In fact, the British government in Bombay showed almost paranoid concern about American contact with Said. A British resident in the Gulf informed the Bombay government of the Omani-American Treaty of 1833, further reporting Said's alleged offer of an American settlement on the African mainland if the U.S. would agree to assist with putting down the Mazrui rebellion in Mombasa. 30 As a result of these reports, the British government at Bombay decided in 1834 to send an official to Zanzibar to investigate this and other rumors concerning American contact with Said bin Sultan emanating from Zanzibar. In February, 1834, the British representative, one Captain Hart, arrived in Zanzibar aboard H.M.S. Imogene. 
Oman and Britain had had diplomatic relations since the late eighteenth century. Between 1789 and 1800 the two governments (Britain represented by its administration in Bombay) signed a number of treaties forbidding Oman's commercial intercourse with the French and Dutch during their war with the British. 31 However, there was nothing in these treaties that would prevent Said from entering into commercial treaties with the United States. On the other hand, British-Omani ties were close. Said had supported the British military expedition against the Qawasim in the Gulf in 1819, while in turn the British had supported Said's claim over Mombasa in 1824. 32 Understandably, then, the British were concerned over these new rumors.

However, in meetings with Said at his palace, Captain Hart found that the 1833 treaty with the U.S. was perfectly innocent. There were no provisions for the concession of territory nor the grant of American military aid for use against the Mazrui in Mombasa. 33 Hart reported to his government, then, that nothing more was afoot in Zanzibar that increased American commercial activity, resulting in nothing more than greater competition for the British. 34 However, Hart also brought to Said's attention that the British enjoyed no commercial treaties of the kind just concluded with the United States, and that surely Britain deserved such trading advantages even more than did the Americans. 35 Said assured Hart that he was committed to British friendship and that he would give Britain the same commercial advantages that Americans enjoyed through the treaty. 36 The result of this promise was the signing of the British-Omani treaty of 1839. 


\section{ROBERTS' THIRD VOYAGE}

Roberts returned to Washington flushed with the great success of his diplomatic mission, the negotiation of trade agreements with both Muscat and its possessions and with the Kingdom of Siam. Roberts' success constituted the first American diplomatic contact with an Asian country in which American commercial interests in South Asia and the Indian Ocean would be enhanced. President Jackson expressed his gratitude to Roberts, and the Senate ratified the Omani-American Treaty without significant dissent on June 30,1834 . Roberts was selected and authorized to exchange the ratified treaty with Oman. 37 Before leaving the U.S. on his mission to exchange ratified treaties, Roberts received instructions and arrangements from Secretary of State John Forsyth, which indicated he would visit Japan for the same purpose once his business in Zanzibar was complete.

On March 25, 1835, Roberts once again sailed for Oman, reaching Zanzibar with two vessels in September. Sayyid Said was absent, but Roberts was welcomed by Khalid bin Said, governor of Zanzibar, who welcomed them royally. Shortly thereafter, Roberts continued with a small group aboard one of their ships, the Peacock, to Muscat for the purpose of exchanging ratified treaties with Said. En route, however, the Peacock struck a coral reef and ran aground on Masira Island, an Omani possession some 400 miles from Muscat. Short of water and other provisions, and fearful of their vulnerability to pirates, Roberts along with six others departed the stricken ship in a small boat and set out for Muscat, which they reached in three days. Sayyid Said immediately dispatched armed rescue parties to assist the Peacock, but 
before they reached the ship, the Peacock managed to refloat itself and proceeded to Muscat unassisted. 38

Immediately, Roberts and Sayyid Said set to work on the formal notifications concerning the treaty. The only obstacle was to determine the exact date the treaty would go into effect. Said asked Roberts to set the day, and they then agreed on June 30,1834, which was the date of the treaty's ratification in the United States. All American merchants who had sailed after this date were entitled to rebates on fees they had already paid in transacting business in the Sultan's ports. 39

Roberts' work in Muscat successfully completed, he at last departed for Siam to complete the transfer of a treaty he had formed with that country. Unfortunately, however, Roberts did not live to see the fruit of his labors. He contracted a fever in Siam and died in Macao on June 12, 1835, at the age of fifty-one. He was buried in Macao's East India Company cemetery while the guns of the Peacock fired a final salute. 40 On December 6, 1836, President Jackson informed the Senate that ratification of the Omani-American treaty had been duly exchanged--a treaty, he say, "which promised great advantages to our enterprising merchants and navigators. ${ }^{.41}$

Thus, Roberts' diplomatic efforts set the stage for the future of relations between the United States and Oman. A treaty was in place, relations were friendly, and the way was open for unlimited commercial development. The first American Consul was to reach Zanzibar just a year later, in 1837, and Muscat just a year after that. Through Roberts' efforts, the door to trade throughout Oman and East Africa had been opened to merchants from the United States. 


\section{ENDNOTES}

1 Eilts, Hermann F. The United States and Oman: 150 Years of Friendship, Muscat: Ministry of National Heritage and Cultare, 1985, p. 4.

2 Phillips, James Duncan. Salem and the Indies, Boston: Houghton Mifflin, 1947, p. 186. Morison, Samuel E. Maritime History of Massachusetts, 1783-1860. Boston: Houghton Mifflin, 1931, p. 92. Gates-Hunt, Richard H. "Salem and Zanzibar: A Special Relationship," Essex Institute Historical Collections, CXVII (January) 1981, pp. 20-21.

3 Eilts, The United States and Oman, p. 4.

4 Gray, Sir John M. History of Zanzibar from the Middle Ages to 1856, London: Oxford U. Press, 1962, p. 194.

5 Northway, Philip E. "Salem and the Zanzibar-East African Trade, 18251845," Essex Institute Historical Collections, Vol. XV (April) 1954, p. 128.

6 Bennett, Norman R., “Americans in Zanzibar: 1825-1845,” Essex Institute Historical Collections, XCV (July) 1959, p. 239.

7 Putnam, George B. "Salem Vessels and Their Voyages," Essex Institute Historical Collections, LXV (April) 1929, p. 133.

8 Eilts, The United States and Oman, p. 4. Bennett, "Americans in Zanzibar: 1845-1865, p. 241.

9 Essex Register. Salem: Essex Institute, June 19, 1826. Bennett, pp. 241242.

10 Brady, Cyrus T. Commerce \& Conquest in East Africa. With Particular Reference to the Salem Trade with Zanzibar, Salem: Essex Institute, 1958, p. d-55. Northway, p. 128.

11 Duignan, Peter and L. H. Ganan. The United States and Africa: A History, Cambridge: Cambridge Univ. Press, 1984, p. 72. 
12 Eilts, Hermann F. “Ahmed Bin Na'man's Mission to the United States in 1840: The Voyage of Al-Sultanah to New York City," Essex Institute Historical Collections, XCVIII, p. 227. Berman, Edward H. "Salem and Zanzibar, 1825-1850, "Essex Institute Historical Collections, CV (October) 1959 , p. 340. Bennett, Norman R. and George E. Brooks. New England Merchants in Africa: A History through Documents, 1802 to 1865, Boston: Boston University (unpublished), p. 24.

13 Brady, pp. 89-90.

14 Eilts, Hermann F. “Edmund Q. Roberts, 1784-1836: A Diplomatic and Personal Memoir." Boston: Boston University (unpublished), p. 24.

15 Gray, p. 124. Eilts, Ahmed Bin Na'man's Mission, p. 228.

16 Coupland, Sir Reginald. East Africa and Its Invaders, From the Earliest Times to the Death of Seyvid Said in 1856. New York: Russel and Russel, 1938 , p. 367. Howard, Lawrence C. "American Involvement in Africa South of the Sahara, 1800-1860" (Ph.D. dissertation). Boston: Harvard University, 1956, p. 84.

17 Bennett, “Americans in Zanzibar, 1825-1845,” p. 244.

18 Howard, p. 84. Coupland, East Africa and Its Invaders, p. 367.

19 Mallory, Lowry. “American-East African Relations, 1827-1861” (Ph.D. dissertation), Texas Christian University, 1976, p. 8.

20 Haight, M. V. J. European Powers and Southeast Africa: A Study of International Relations on the Southeast coast of Africa, 1796-1856. London: Routledge \& Kegan Paul, 1942, p. 229. Howard, p. 84.

21 Essex Register, June 24, 1832. Salem: Essex Institute. Howard, p. 84. Brady, p. 90.

22 Edward Livingstone to Edmund Roberts, January 27, 1832, "Special Missions," Micro. 77, Roll 152; quoted in Bennet, p. 245. Miller, H. (ed.). Treaties and Other International Acts. The United States of America, vol. 3. Washington, DC: GPO, 1933, p. 802.

23 Miller, p. 802.

24 Wriston, Henry M. Executive Agents in American Foreign Relations, Gloucaster, Mass.: Peter Smith, 1967, pp. 366-377. 
25

Ibid, p. 366.

26 Clendenen, Clarence, and Peter Duignan. Americans in Black Africa up to 1856 , p. 32 . Haight, p. 246. Howard, p. 85. Wriston, p. 337.

27 Roberts, Edmund. Embassy to the Eastern Courts, pp. 361-363. Edmund Roberts to the U.S. State Department, June 2, 1835, "Special Agents," vol. 10 .

28 Miller, pp. 790-797.

29 Eilts, Roberts Memoir, p. 232.

30 Kelly, J.B. Britain and the Persian Gulf, 1795-1880, Oxford: Clarendon Press: 1968, p. 236. Haight, p. 245. Clendenen and Duignan, p. 32.

31 Eilts, Roberts Memoir, p. 237.

32 Al-Qasimi, Sultan Mohammad. “The Myth of Arab Piracy in the Gulf” (Ph.D. dissertation), Croom Helm, New Hampshire: 1985, pp. 84-85 and p. 184.

33 Kelly, p. 236.

34 Hart, C. "Extracts from Brief Notes of a Visit to Zanzibar" (selections from the records of the Bombay government), Vol. XXIV, 1856. In T. R. Huges (ed.) Arabian Gulf Intelligence, New York: Oleander Press, 1985, pp. 280281.

35 Graham, Gerald. Great Britain in the Indian Ocean: A Study of Maritime Enterprise, 1810-1850, Oxford: Oxford Univ. Press, 1967, p. 206.

36 Tbid., p. 205.

37 Paullin, Charles O. Diplomatic Negotiations of American Naval Officers. 1778-1883, Baltimore: Johns Hopkins Univ. Press, 1912, p. 352-353. Mallory, p. 15.

38 Ruschenberger, W.S.W. A Voyage Around the World. Including an Embassy to Muscat and Siam in 1835, 1836, and 1837, Philadelphia: Carey, Lea \& Blanchard, 1838, pp. 42-43. 
39 Roberts, Edmund to John Forsyth (Bombay, October 23, 1835). "Special Agents," vol 10, Washington: National Archives. Bennet \& Brooks, pp. 160-163. Ruschenberger, p. 88.

40 Kennedy, Edmund P. "Special Agents," (Memo to the State Department from Macao), June 12, 1836.

41 Journal of the Senate of the United States of America, (24th Congress, 2nd Session) nos. 296-307, Washington: 1836, p. 8. 
CHAPTER III

THE WATERS YEARS, 1837-1845

\section{SAID BIN SULTAN CONSOLIDATES POWER IN EAST AFRICA}

During the period of Edmund Roberts' shuttle diplomacy between Washington and Muscat to promote the ratification of the Treaty of 1833 , the frequency of visits of American vessels to the port of Zanzibar continued to grow. American merchants were creating a virtual economic monopoly. During the two-year period of 1832-1834, for example, 32 of 44 ships visiting Zanzibar were American. Twenty of these originated in Salem, three each from New York and Boston, while the remainder were from unspecified American ports. In contrast, during the same period only seven British vessels and one each from France and Spain called at the port. However, while Zanzibar prospered, the port of Muscat saw the arrival of only one vessel in the seven-year period prior to $1835 .^{1}$

At the same time, Said bin Sultan began turning his attention to East Africa for the purpose of establishing political and economic power in the region. He encountered an obstacle, however, in the existing influence of the Mazrui family of Mombasa, who stood opposed to his influence and refused to recognize his authority in Mombasa. The Mazrui family ruled in Mombasa as governor (Wali) for the Yaaruba Dynasty, who had dominated the region since driving the Portuguese out of Fort Jesus in Mombasa in $1698 .^{2}$ By the year 1700, the entire coast of East Africa had passed into the hands of the 
Yaaruba, who in turn appointed several governors (or Wali) in the important coast towns and islands. Among these was Nasir bin Abdulla, head of the Mazrui family, who was appointed Wali of Mombasa.

On the other hand, Ahmed bin Said was elected Imam in 1747 and ruled Oman and East Africa in the name of the Al-Busaid family since that time. But the Mazrui governor of Mombasa refused to recognize Said's sovereignty and declared independence. ${ }^{3}$ During the first twenty years of his reign, however, Said was too fully occupied with troubles in Oman and the Arabian Gulf to give a great deal of attention to East African possessions. In 1822 he sent his first military expedition to subdue the Mazrui. However, this military expedition failed.

At this time the Mazrui asked the British for protection in maintaining their power in Mombasa, but the British governor in Bombay refused the request. However, their request was granted by a Captain William Owen, who signed a protection agreement on February $8,1824 .{ }^{4}$ On July 25, 1826, though, the British government nullified Owen's agreement, citing Britain's Treaty of 1822 with Sayyid Said, under which he assisted the British in crushing the Qawasim power in the Gulf. 5 Thus, the Mazrui lost their British protection and their position was rendered perilous.

On January 7, 1828, Said bin Sultan himself led a large military expedition against the Mazrui, but it failed to subdue them completely. Upon his arrival in 1828 in Zanzibar he made his first contact with an American official, Edmund Roberts. He discussed with Roberts future Omani-American relations, a discussion which eventually culminated in the Treaty of 1833.

Between 1822 and 1837 Said made several attempts at subduing the 
Mazrui by military means, but not until February of 1837 did he finally succeed at overcoming them. The Mazrui's ruler, Rashid bin Salem, and sixtysix of his supporters were exiled to Bandar Abbas, and Said's power in East Africa and Zanzibar was solidified. 6

\section{THE CAPITAL IS MOVED TO ZANZIBAR}

In the course of his lengthy military effort to gain control over East Africa, Said began the development of the economic system in East Africa, and in 1832 he decided to move the capital of his realm to Zanzibar. This he did in 1840. There were several reasons for Said's move, most prominently his tenuous grip on the Wahabbis threat and internal disputes. Furthermore, his military expeditions to capture Baharin had failed, so that he settled on a strategic position between the mainland of East Africa and the western shores of the Indian Ocean from which to oversee his realm. Lastly, Zanzibar had a good harbor, a favorable climate, and fertile soil. These features would enhance Zanzibar's attractiveness as a trading center, thereby contributing to Said's wealth. 7

Said took other steps as well to improve Zanzibar's attractiveness as a trading center. In 1828 he introduced the cultivation of clove trees, a crop that had only previously been known to grow in the East Indies. He ordered the landowners of the islands of Zanzibar and Pemba to cultivate the crop, which eventually became an economic mainstay of Zanzibar. By the 1860s, Zanzibar had become the world's major producer of cloves. 8 Other measures to enhance Zanzibar's economy included creating liberal customs policies to attract foreign merchants. He also allowed Indians to trade in Zanzibar, who 
brought with them administrative and financial skills that Said felt were essential to developing a trading center. ${ }^{9}$

Said's greatest accomplishments, however, were the treaties he negotiated with the United States (1833), Great Britain (1839), and France (1844). With this foundation, Said was in a position to develop an economic and political hegemony over most of East Africa. The success of his policy was in many ways symbolically recognized in 1837 with the arrival in Zanzibar of the American Consul, Richard P. Waters, the first foreign consul to be posted in Said's new capital.

\section{RICHARD P. WATERS ARRIVES IN ZANZIBAR}

Waters was from Salem, Massachusetts, was a merchant, and in 1832 became involved in the abolitionist movement. He became a member of the Essex County Anti-Slavery Society in 1836 and in that context became friendly with the Reverend James T. Woodbury, brother of Levi Woodbury, Secretary of the Navy to President Andrew Jackson. With this background, Waters circulated comfortably in both commercial and political circles. His friends and acquaintances included on the one hand John Bertram and Michael Shepard of the trading company that bore their names, and on the other hand included political figures such as ex-Senator Silshue and Representative Stephen C. Phillips. 10

When the post was first established, Waters became interested in receiving the consular position in Zanzibar. Commercial and political acquaintances encouraged him to apply for the position, and in February, 1836, Waters visited Washington, where he was introduced to President 
Jackson by Representative Phillips. Waters was subsequently appointed to the position of American Consul to Zanzibar. ${ }^{11}$ Prior to his departure in October, 1836, Secretary of State John Forsyth gave Waters his diplomatic instructions. He was instructed not to take commercial advantage of his position, but must adhere to the "usual privileges" granted by the treaty of 1833. Furthermore, he was not to exploit the fact that the consul's person and property were diplomatically inviolate. 12 This last instruction derived from the fact that during that period consuls were more frequently commercial than diplomatic agents. They received nominal salaries from the State Department, but their primary financial support came from their roles representing commercial firms in their post. However, Waters was not affiliated with any single commercial firm at the time he arrived at Zanzibar.

Waters' reasons for wishing to go to Zanzibar were varied. A businessman as well as devoutly spiritual, his reasons were at once both religious and commercial. In his diaries he expressed his convictions: "I have desired to be made useful to the souls of these pagans among whom I am called to reside. That my going to dwell with them . . . may be a means of introducing the gospel of Christ to them ... that the way may soon be opened for missionaries to reside there." 13 At the same time, however, his economic interests were not altogether subordinate. As he expressed it in his diaries once again, "I want money for my own sake, for my dear mother, sisters and brothers sake, and to do good with."14

Waters arrived in Zanzibar on March 18, 1837, and was welcomed in the harbor by Omani officials. "They all welcomed me to Zanzibar," he recorded in his diary; "I invited them to take a glass of wine with me, but they 
declined by saying that it was against their religion to drink wine; they drank a tumbler of lemonade. $\$ 15$ On the following day Waters was given a reception by Sayyid Said, at which Said invited him to sit in his own place of honor at the table. In Waters' words: "He [Said] received me with great apparent good feeling, and invited me to take the seat which he always occupied. 16 Waters presented his diplomatic credentials along with a letter to Said from President Jackson. In the letter the president expressed his thanks to Said for his assistance to the ship Peacock, and he went on to express his wish that they promote a strong relationship between the two countries. For his part, Sayyid Said was so pleased with Waters and his posting as the first American Consul in his country that he offered him any house in Zanzibar he might wish, and further offered to furnish and provide it to the new American Consul at no charge. 17 The dominant tone, then, was that Waters was as much a friend to Said as he was diplomatic representative of the United States. Said frequently invited Waters to his plantation to visit and go riding. Said also provided not just a horse, but also put a boat at Waters' disposal for the conduct of his duties in Zanzibar.

Waters was in an ideal position to represent not just his government's interests, but also those of his contacts in the Salem trading companies. Over time, Salem's merchants secured a corner on trade with Zanzibar. Recognizing this, another trading firm, Scoville and Britton, wished to secure a corner on the trading market with the Omani port of Muscat. To this end they approached the influential politician, Aurora Parker, with a request that he lobby for the appointment of an American consul in Muscat. He did so, and on the basis of his close ties to the Van Buren administration succeeded in 
persuading them of the need for such a consul. On October 4, 1838, the new American Consul to Muscat, Henry Marshall, arrived in Muscat to take up his post. 18 Marshall, of course, had ties to the trading firm of Scoville and Britton.

Upon his arrival, he was welcomed cordially by Thawani bid Said, governor of Muscat. ${ }^{19}$ However, Marshall did not last long in Muscat. A combination of poor health and the bankruptcy of Scoville and Britton led to his departure after only a few months. Before departing, though, he appointed as acting American Consul the man who had acted as translator of the Omani-American treaty of 1833 , Said bin Khalfan, who was eventually appointed to the full position of consul in Muscat in 1843. This development came about largely due to his affiliation with the trading firm of Bertram and Shepard. In 1845, however, Kalfan died, whereupon his duties reverted to his American associates. ${ }^{20}$ Said bin Khalfan had been considered a leader of a group of an anti-British persuasion. Their sympathies were strongly proAmerican. He provided a variety of consular services for visiting American captains as well as serving as the principal Omani merchant and broker for American trading vessels. 21

Thus, while Said bin Khalfan represented American interests in Muscat, Waters was doing the same at Zanzibar. Unfortunately, though, Waters encountered difficulties in Zanzibar with the master of the Customs House, Jairam Sewji. 


\section{THE WATERS-SEWJI MONOPOLY}

Jairam Sewji was a leading member of the Indian community of merchants prominent in nineteenth century Zanzibar. A businessman and proprietor of his own firm, he had close ties with Sayyid Said. In fact, Sewji rented the concession to the Zanzibar custom house, which in 1835 totaled $\$ 150,000$. His contract with Said was for five years, renewable for another five, with the rental increasing steadily throughout the period. Over twenty years from 1860 to 1880 , rental on the custom house concession increased from $\$ 196,000$ to $\$ 500,000.22$

Sewji maintained control of the custom house until his death in 1886. By then he had amassed a great fortune, leaving $\$ 3$ million in cash in his will. ${ }^{23} \mathrm{He}$ was unquestionably a very powerful man in commercial circles, controlling the import and export of all goods through the port of Zanzibar as well as on the coast through his agents.

When Waters arrived in Zanzibar he faced difficulties with Sewji almost from the start. For example, Sewji not only required that all American merchants bring their exports to the custom house for inspection, but further required that they pay the cost of laborers to transport the goods to and from the custom house. Of course, Sewji controlled the laberors. In addition to this, Sewji charged all Banyans who did business with American merchants a five percent duty on their goods sold to compensate for the loss of export taxes he was unable to charge due to provisions of the Omani-American Treaty of 1833. Waters protested these actions to both the State Department and to Said, as he feared Sewji's actions might threaten or inhibit American trade. 
Although Said expressed his overall support of Sewji, he did act to stop him from exacting the forced charges for labor as well as the five percent duty he was charging on goods sold to American traders, but only on the condition that the United States government officially protest these actions as in violation of the Treaty of 1833. Unfortunately, however, the U.S. State Department's position was that the issues were too minor and did not merit formal protest. Nonetheless, in the aftermath Said promised Waters that he would end the charging of the five percent duty. 24

With time, however, Waters ceased his protestations against Sewji's activities, deciding that he was better off cooperating than struggling with him. In the interest of profitability, the two formed an alliance that enabled them to dominate the import-export trade in Zanzibar as well as exclude both the English and any American traders who refused to deal through them. In short, as master of the custom house, Sewji could block, or at least make very difficult, any transactions that Waters did not approve, which gave Waters priority over all other foreign merchants on the island of Zanzibar. In exchange, Sewji was given a monopoly position as broker for the Salem merchants, determining what goods were sold, to whom, and at what price. 25 The best of all possible descriptions of the Waters-Sewji monopoly of the Zanzibar trade is contained in Waters' own words, in his instructions to his vice-consul P.S. Parker on the occasion of Waters' temporary absence from Zanzibar in 1840 :

On the arrival of any American vessel in Zanzibar, the captain will visit you soon after the vessel comes to anchor. It will be your duty ... to state all you know about the market, the prices, and probable quantity in the market of such articles as they may wish.

After you have engaged to do the business of any vessel, you will 
do well to hold a conversation with Jairam bin Seva [Sewji], the custom master. Inform him what the vessel has to sell and what she wishes for return cargo .... He will propose at once to call the merchants together at my house; show them the samples of cotton and fix a price for them. Should the captain conclude to sell at the offers made, Jairam will be the person to whom you will deliver the goods and also charge them to, he being the only person you are to know in the business .... Before you conclude the sale, you will talk to Jairam in regard to what you may want for return cargo. 26

Thus, the Waters-Sewji system monopolized all trade passing through Zanzibar. Merchants wishing to trade had no alternative but to deal with this partnership. Some protested, notably the British merchant Robert Brown Norsworthy, who took his protest to both Said and to the British Consul Hamerton, but to no avail. 27

Both Waters and Sewji made considerable fortunes under their joint monopoly. Sewji's greatest source of income, despite the considerable duties he was collecting, was his commissions as broker for the American trade. Waters, too, enjoyed income as a businessman and broker for American, and particularly Salem, trading firms. In 1839 he wrote to his brother William that "Jairam and myself are on the best of terms. He respects me and fears me and at the same time I have his confidence. I do nine-tenths of my business with Jairam. 28

And because of this arrangement, and because of Waters' ties to the Salem trade, it was the Salem traders who enjoyed the majority of the trading opportunities in Zanzibar, and largely free of interference from foreign (i.e., British) or other American competition. Between 1837 and 1840, Waters represented the interests of the Salem firm of Bertram and Shepard, whose officials has worked to secure his appointment as consul, and in 1840 
he became agent for the firm of Pingree, West. ${ }^{29}$ Their control was so great, in fact, that the British trading firm of Newman, Hunt and Christopher gave up and abandoned the Zanzibar trade. From 1837 to 1841 American merchants were left free to dominate the Zanzibar trade specifically due to conditions created by the Waters-Sewji alliance. 30

\section{BRITISH CONSUL HAMERTON}

It was under these conditions that in May, 1841, the first British Consul to Zanzibar, Captain Hamerton, arrived on the island. Hamerton was shocked by the decline of British influence in Zanzibar. Not only were the Americans in full control of commercial activity passing through the port of Zanzibar, but that they enjoyed virtually a total political monopoly as well, discovering that Sayyid Said was surrounded by an Omani political faction which favored the Americans over the British.

When Hamerton first visited the Sultan's palace, therefore, he was greeted with great disrespect. A number of the Sultan's officials spoke loudly of the wealth and superiority of the Americans. Furthermore, Hamerton observed in the palace two paintings hung up on either side of the Sultan's chair in the royal reception room: "The subjects were naval engagements between American and English ships; the ship of England is represented as just taken by the American, and the English ensign is being hauled down and the American hoisted at the masthead." 31 This was Hamerton's first impression of the political climate in Zanzibar.

However, the British were Oman's allies in the Gulf. The two countries had signed the Mosely Treaty of 1822 as well as the Commercial Treaty of 
1839. Said may have wished to demonstrate to the British through Hamerton that there were alternatives to an alliance with the British, but the fact remained that the British were the dominant military power in the Indian Ocean. Hamerton made this point, and the next time he visited the Sultan he observed that the paintings which had previously been hung in the visiting chamber had been replaced by one depicting the British defeat of the TurkoEgyptian fleet at Navarino in 1827.32

Hamerton was not so easily swayed. He had no illusions, despite the gesture of the paintings, that the Americans clearly dominated both political and commercial activity in Zanzibar. His mandate from the British government was that he should arrive in Zanzibar to protect British interests, both political and commercial, and to influence suppression of the slave trade. For these tasks he was well prepared. At thirty-seven years of age, he was a veteran of military service in India, where he rose to the rank of captain, and was an agent of the East India Company. He had some diplomatic experience and spoke Arabic well. Hamerton was well prepared to serve British interests in Zanzibar. 33

At the time Hamerton arrived in Zanzibar, Waters happened to be on a trip back to America, settling business in Salem. An indication of the closeness of the relationship between Waters and Sayyid Said is in the latter's offering Waters use of his private vessel, the Sultanah, which was embarking on a trip for New York. 34 Waters declined the offer, however, and embarked in his brother's ship. Waters returned to Zanzibar in June, 1841.

Hamerton proceeded to launch a campaign to break up the WatersSewji monopoly. As a representative of the Bombay government and protector 
of the British and Indian trade, he had little other choice. As early as June 28 he wrote to Sayyid Said complaining that Waters and Sewji had prevented a British merchant from trading unless he agreed to pay commissions to Waters and Sewji. Hamerton expressed his indignation to Said at such an arrangement, particularly when it so blatantly discriminated against British commercial activity. 35 In Hamerton's other role, that of political representative of the British Crown government, he felt obliged to also work toward weakening the significant political influence the Americans possessed in Zanzibar. Such an effort, he felt, required a little propaganda. For example, Hamerton took pains in a letter to Lord Palmerston to describe the voyage of the Sultan's ship the Sultanah to New York. He narrated a voyage in which Said's sailors were tormented continually by a mob who crowded around to see the Arab workers, whom they looked upon as curiosities, invading their privacy and offering personal insults like pulling on their beards. 36 This was Hamerton's idea of undermining Omani-American relations.

In fact, the true story of the voyage of the Sultanah was far more prosaic. It was bound for New York, where it arrived April 30, 1840, bearing letters and very fine and valuable gifts for President Martin Van Buren. Unfortunately, the timing was awkward. President Van Buren was in the midst of the 1840 presidential campaign, and his opponents in congress and the press seized on these gifts from the Sultan and made them into a campaign issue. After long debate and congressional action, the gifts were made property of the U.S. government, some sold off and their proceeds added to the U.S. treasury, others held simply in the name of the U.S. government. 37 In this way the issue was finally resolved, its intended 
purpose of simply slinging mud at an incumbent presidential candidate having been accomplished.

Despite this partisan political haggling, the visit of the Sultanah and its officers, and of Sayyid Said's representative, Ahmad bin Na'aman, was a diplomatic success. They were feted in New York, were received by the mayor of the city, given special gifts and tours, and generally royally received. Ahmad bin Na'aman received gifts from the U.S. government for Sayyid Said. The significance of this first Arab mission to the United States is highlighted in the work of Professor Eilts: "Hopefully, therefore, these paragraphs may draw back the curtain of obscurity which time has draped over Ahmad bin Na'aman and recall briefly a forgotten, but deserving, first Arab mission to our shores."38

For his part, Hamerton continued his campaign to weaken American influence. Early on he decided that Ahmad bin Na'aman was the leader of the pro-American group in Zanzibar, a group that Hamerton called bitterly "The American Party," and which he believed had persuaded Sayyid Said to take a strong anti-British stance in Zanzibar. ${ }^{39}$ And of course, Hamerton was correct. The pro-American party, with Waters at the nominal head, took great pains to weaken the British position in Zanzibar. For example, they persuaded Said to require that Indians sign a declaration giving up their British citizenship and accepting Omani sovereignty. However, the Indians refused, the British protested most vigorously, and Hamerton eventually won out on this issue. 40 Waters also went so far as to lie outright upon return from a visit to Bombay, telling Said that British power in India was in ruins, their troops defeated, and their foreign agents (i.e., Hamerton) acting without 
authority. 41

However, by 1842 Hamerton was able to report to his government that his activities had succeeded in breaking the American monopoly in Zanzibar and that British subjects finally enjoyed equal rights of trade. ${ }^{42}$ Hamerton took full credit for this development. In fact, though, there was a complex array of factors and developments which led to the breakdown of the WatersSewji monopoly and American dominance in Zanzibar.

\section{COLLAPSE OF THE AMERICAN MONOPOLY IN ZANZIBAR}

Between 1837 and 1841 Waters was easily able to control, manipulate and dominate the Zanzibar economy, primarily because it was small, outside political influences were few, and the local political structure was amenable to his designs. However, through the 1840 s the port grew, outside interests (particularly those of the British), and the general economic climate developed in such a way that even an adept manipulator would be hard pressed to manage developments. A great many more American and European vessels were visiting Zanzibar and Waters found himself less and less able to control the market. Sewji also balked. He wished to end his relationship with Waters, since the great increase in the volume of trading no longer made it practical to restrict trade.

Waters saw Hamerton as being to a large degree the instrument of the downfall of his economic monopoly, and the remainder of their time in Zanzibar saw hostile and strained relations between them. Said, too, disliked Hamerton, whom he felt was vain, proud, and condescending. ${ }^{43}$ In fact, in 1844 Said wrote the British Foreign Office requesting that Hamerton be 
removed from his post. Britain's Lord Aberdeen responded to Said's letter and apologized for Hamerton's behavior and ordered his removal. 44 But the Bombay government was unwilling to remove Hamerton because he was so highly qualified, including the fact that he spoke Arabic. At the same time, in London Aberdeen was succeeded by Palmerston, and the result was that Hamerton retained his position. His relations with Sayyid Said improved and Hamerton remained British consul at Zanzibar until his death in 1857.

Another consequence of the breakdown of the Waters monopoly was that the competitive edge previously enjoyed by Salem traders broke down. As a result, competition among American trading firms became intense. However, the early edge enjoyed by the Salem traders proved advantageous, and the Salem firm of Bertram, Shepard controlled American trade in the region for the bulk of the $1840 \mathrm{~s}$ and $1850 \mathrm{~s} .{ }^{45}$ However, achieving this dominant position had not been easy, nor particularly ethical. Bertram, Shepard got their early edge from Waters, who was their agent in Zanzibar until 1841, when he jumped firms and became an agent for Pingree, West. At that time Bertram, Shepard sent another agent to Zanzibar, one John F. Webb. For three years after this the competition for dominance between the two big firms was fierce. It was so fierce, in fact, that it eventually threatened the profitability of both. In 1844, the two firms colluded and agreed to end their competitive practices and entered into a cooperative effort to share trade and to the best of their ability block access to Zanzibar for other American and European merchants. 46

The collapse of the Waters-Sewji monopoly marked the end of Waters' tenure in Zanzibar. Citing health reasons, Waters resigned his post and 
departed Zanzibar for the United States in July 1845.47 He never again returned to Zanzibar, although he and Said corresponded regularly, and the Sultan frequently sent him gifts.

\section{THE WATERS LEGACY, IN RETROSPECT}

When Sayyid Said lost Waters, he lost a valuable friend and associate. If his methods appear somewhat less than ethical from a present-day view, to Sayyid Said his presence was invaluable. Their relationship was personal and professional, political, economic and cultural. He did everything from translate American newspaper articles for the Sultan to advising him in the negotiation of commercial treaties with European countries. A good illustration of the role Waters played for the Sultan may be seen in a letter from him to his brother John:

The French brig of war Messenger is here for the purpose of making a commercial treaty with his highness, the Sultan, and I have been entrusted by his highness with the business of arranging a treaty. I have been busily engaged on the subject the last ten days--and much to the satisfaction of his highness and his sons. To arrange this treaty was one of the objects which induced me to remain here this year, as his highness was very desirous for me to take charge of the matter on his behalf. 48

Waters had been, after all, the first diplomatic representative of a Western nation to take up a post in Zanzibar. His tenure coincided with the evolution of Zanzibar from a trading backwater to a prominent port of call and a busy harbor. Whereas American merchants were a rarity in 1837 , by 1845 they dominated the East Africa trade. Despite this, however, Waters unquestionably abused his post and his influence with the Sultan, not only politically in the course of influencing the development of commercial treaties, but also commercially, in his manipulation of the local political scene 
to the advantage of his commercial liaisons and to the detriment of others. It was clearly not only unethical, but also illegal, for the American Consul to negotiate on behalf of a foreign country.

However, Waters had a fair record as a diplomat, working vigorously toward the resolution of disputes between American vessels and the local government. This was particularly apt to occur in connection with the visits of American whaling vessels, when not infrequently crews would attempt to jump ship in Zanzibar, usually complaining of unfair treatment by the ship's officers, or of poor food or living quarters. Several of these incidents are on record, and in each Waters performed fairly and well. Some of those recorded include the incident of the whaler London Packet ${ }^{49}$, the whaling ship Emma $^{50}$, and most particularly in the case of the whaling ship Styx, aboard which was the writer John Ross Browne engaged in the writing of his book, Etchings of a Whaling Cruise. 51

Although Waters was tough on whaling ship crews, he was a friend of the missionaries. He introduced arriving missionaries to Sayyid Said and encouraged them to stay in Zanzibar. In the words of a German missionary, Herr Krapf: "Mr. Waters, the American Consul, was a zealous friend to the mission. He wished me to remain in Zanzibar preaching on Sundays to its few Europeans; working among the Banyans from India; founding schools for the instruction of the native Swahilis and Arabs; and preparing books in the languages of the mainlands . . .52

One of Waters' most important diplomatic achievements involved removing the ban on the selling of guns and powder in Said's dominions. The Omani-American commercial treaty of 1833 had banned the free sale of guns 
and powder to anyone except the government of the Sayyid Said. The Sultan had insisted on this provision at the time of the treaty's negotiation, since at the time he was at war with the Mazrui. However, in 1838 Waters informed the Secretary of State that the Sultan had agreed to allow the American to sell guns and powder at their discretion in Said's lands. 53 On a more personal level, at Waters' request, Sayyid Said designated a plot of land to become a Western (i.e., Christian) cemetery. 54

The single major issue that Waters failed to accomplish in his time in Zanzibar, and which was to become the center of a great crisis in the administration of his successor, Charles Ward, was the issue of direct trade on the coast of East Africa. This had always been forbidden to the French and English, but was permitted for Americans under Article II of the Treaty of 1833. Said had withheld this trading from the British and French because he feared their presence on the coast would threaten his political and economic position. In 1833 he had no such fear of the Americans, since their economic and military power in the region was very limited. This was to change, however, and Sayyid Said soon repudiated Article II of the treaty and forbade Americans access to direct trade on the East African coast. The State Department contacted Waters and instructed him not to pursue the issue. Waters was in this way spared what could have become an intense crisis with his good friend the Sultan. Instead, the crisis was passed to his successor, Consul Charles Ward. 


\section{ENDNOTES}

1 Thomas R. Hughes (ed.), Arabian Gulf Intelligence, pp. 280-282. W.S.W. Ruschenberger, p. 84. Norman R. Bennett, p. 248. Sir Reginald Coupland, East Africa and its Invaders, p. 375.

2 Ahmed H. Al-Maamiry, Oman and the Coast of Africa, New Delhi: Lancer's Books, 1985. Patricia Risso, Oman and Muscat: An Early Modern History, New York: St. Martin's Press, 1985, p. 13.

3 Gamal Z. Qasim, Dawlat Bu Said, 1741-1861, Cairo: Modern Cairo Library, 1967, p. 25. Al-Maamary, p. 69.

4 Gamal Qasim, pp. 197-201.

5 Coupland, East Africa and Its Invaders, pp. 264-270.

6 S.B. Miles, The Countries and Tribes of the Persian Gulf, p. 340. Sir John Gray, History of Zanzibar, p. 135.

7 Ali Abdullah Al-Farsi, Omani-Persian Relations During Al-Bu-Said's State. 1741-1871, Alexandria: University of Alexandria, 1989, p. 149. Risso, p. 130.

8 J.D. Fage and Oliver Roland (eds.), The Cambridge History of Africa. From 1790 to 1870 (vol. V), London: Cambridge University Press, 1976, p. 275. W.S.W. Ruschenberger, p. 71.

9 Abdul Sheriff, "The Rise of a Commercial Empire: An Aspect of the Economic History of Zanzibar, 1770-1873." Dissertation. London: London University, 1971, p. 412.

10 Waters, Richard P. “Richard Palmer Waters: A Sketch,” Bulletin of the Essex Institute, vol. XX (1888), pp. 174-183.

11 Ibid., p. 176.

12 John Forsyth to Richard P. Waters, April 27, 1836, National Archives, I. Bennett, p. 250. Mallory, p. 240. 
13 Waters, Richard P. Diaries, January 1, 1837, Box 4, Peabody Museum. Norman R. Bennett and George E. Brooks, Jr. (eds.), New England Merchants in Africa: A History Through Documents, 1802-1865. Boston: Boston U. Press, 1965, p. 189.

14 Waters, Diaries, August 19, 1837.

15 Tbid., March 18, 1837.

16 Tbid., March 20, 1837.

17 Ibid., March 21, 1837.

18 Parker to John Forsyth, January 22, 1838, National Archives.

19 Ibid., October 21, 1838.

20 Said bin Khalfan to Said, June 9, 1843, in Richard P. Waters Ms., Box I. Essex Institute. Eilts, Hermann F. Ahmad bin Na'amon's Mission to the United States in 1840, p. 233. Eilts, Herman F. The United States and Oman, p. 18.

21 Ibid., p. 18.

22 Richard P. Waters to John Forsyth, May 6, 1837, Waters Ms., Box 3 p.m. Mangat, J.S. A History of Asians in East Africa, 1886-1945, London: Oxford U. Press, 1969, p. 17. Gregory, Robert G. India and East Africa; A History of Race Relations Within the British Empire, 1890-1939, Oxford: Clarendon Press, 1971, p. 67.

23 Coupland, East Africa and Its Invaders, p. 325. Mangat, p. 18.

24 Mallory, p. 62. Bennett, “Americans in Zanzibar, 1825-1845, pp. 250-251.

25 Duignan and Gann, p. 74.

26 Richard P. Waters to P.S. Parker, January 1, 1840. Waters Ms., Box 9 p.m. 
27 Zanzibar Archives, Muscat, Numbers 3 and 4: R. Norsworthy to Hamerton, June 23, 1841; Hamerton to Said, April 21, 1841; Said to Norsworthy, June 19, 1841. There are several letters in the Zanzibar Archives from Norsworthy to Hamerton, and from Hamerton to Said, regarding the Waters monopoly and the campaign to undermine British mechants.

28 Richard R. Waters to William C. Waters, December 19, 1839, Waters Letter Book, p.m.

29 Gates-Hunt, Richard H. "Salem and Zanzibar: A Special Relationship," Essex Institute Historical Collections, vol. 117 (January, 1981), pp. 20-21.

30 Duignan and Gann, p. 74. Mangat, p. 15. Graham, p. 210.

31 Graham, p. 210. Gray, p. 205. Sheriff, "The Rise of a Commercial Empire," p. 414.

32 Graham, p. 210.

33 Zanzibar Archives, no. 22, Muscat: Hamerton to Sultan Said, May 2, 1841. Mallory, p. 77. Sheriff, p. 413. Gray, p. 242.

34 Waters Manuscript, (date unknown), 1839, Sultan Said to Waters: Box I, Essex Institute.

35 Zanzibar Archive, Muscat, no. 14: Hamerton to Said, June 23, 1841.

36 Gray, p. 213.

37 Eilts, The United States and Oman, p. 22.

38 Eilts, “Ahmad bin Na'aman's Mission,” p. 219-277.

39 Ibid. p. 274.

40 Sheriff, "The Rise of a Commercial Empire," p. 418.

41 Bennett, “Americans in Zanzibar, 1825-1845,” p. 254. Gray, p. 204.

42 Bennett, “Americans in Zanzibar, 1825-1845,” pp. 254-255. 
43 Nicholls, C.S. The Swahili Coast: Politics. Diplomacy, and Trade on the African Coast. 1798-1856, London: Allen \& Unwind, 1971, p. 174-175. Mallory, p. 79.

44 Zanzibar Archives, Muscat, no. 108: Lord Aberdeen to Said, November 27, 1844. Nicholls, The Swahili Coast, pp. 193 \& 237.

45 L. Graz, The Omanis: Sentinels of the Gulf, London: Longman, 1982, p. 11. Eilts, The United States and Oman, p. 10.

46 Northway, “Salem and the Zanzibar-East Africa Trade,” p. 370.

47 Waters Ms., Box 4, p.m.

48 Waters Mss., Box 6, p.m.: Waters at John Forsyth, March 1, 1844. Waters had a copy of the French-Omani treaty of 1844 in both Arabic and English among his papers in p.m., Salem.

49 Waters Diary, in Waters Ms., Box 4, p.m., December 9, 1837.

50 Waters Diary, in Waters Ms., Box 4, p.m., December 30, 1837.

51 Browne, John Ross. Etchings of a Whaling Cruise, (John Seelye, ed.) Boston: Harvard Univ. Press, 1968, pp. 318-326.

52 Krapf, Rev. Dr. J. L. Travels, Researches, and Missionary Labours in East Africa, Trubner \& Co., 1860, p. 122.

53 Waters Ms., Box 3, p.m., Waters to John Forsyth, May 24, 1838; Said to Waters, June 13, 1837.

54 Waters Ms., Box 1, E.I, Waters to Said, June 26, 1838; Said to Waters, June 29, 1838. 


\section{CHAPTER IV}

\section{THE CHARLES WARD AND WILLIAM McMULLAN YEARS, 1845-1856}

On January 20, 1846, Charles Ward arrived in Zanzibar as the second American Consul to Sayyid Said bin Sultan, ruler of Muscat and its dependencies, replacing Richard Waters, who resigned in July, 1845. During his years in Zanzibar, Ward formed strong business ties with the large Salem shipping and trading firm of Bertram and Shepard, for whom he served as agent in Zanzibar. As a consequence of his relationship with this firm, he settled in Salem after his return to the United States in 1850.1

On January 21, 1846, the day after his arrival in Zanzibar, Ward presented his credentials to the Sayyid Said. The meeting went well and the Sultan was impressed enough with Ward to later write to President Polk: "Mr. Ward is a very sensible man and I feel very happy by his arrival. By the blessing of God the friendship of the American nation with the Arab is always and constantly increasing."2 At the outset of Ward's tenure, then, Sayyid Said was quite pleased with the status of Omani-American relations. However, relations between Ward and Said were soon to become strained, and relations between the two countries were to be tested. The breakdown in Ward's and Said's relationship came about for a number of reasons, but the upshot is that it resulted in the most controversial period in the history of early Omani-American relations. ${ }^{3}$ In fact, the controversies introduced during Ward's tenure as Consul ultimately led to the breaking off of 
diplomatic relations between Oman and the United States.

\section{THE ANN PERRY AFFAIR}

Ward's problems with the Omani government began with the first crisis he faced as Consul. This occurred on August 30, 1846, with the arrival at Zanzibar of the American whaling ship, Ann Parry. On the night of August 30, the crew of the Ann Parry. came ashore. They became drunk and disorderly, and fighting broke out between the ship's crew members and some of the local population. During the fighting an Omani customs official named Thabit was struck and later died from his wounds. The crewmen retired to their ship anchored nearby. Consul Ward investigated the incident. The ship's first mate verified the details of the fighting and informed Ward that one of his men had admitted to the killing. 4

Ward then reported to the Sultan in the form of a letter. He informed the Sultan that one man had confessed to the killing, expressed his grief at the loss of the Omani customs official, and suggested that one of the Sultan's judges hold a hearing in the presence of the U.S. Consul. 5 This letter to the Sultan implied a commitment to assist with local justice. However, soon after this Ward sent the Sultan a second letter in which he informed Said that the First Mate had made an error, that the alleged confession was a mistake, and that he found no single crew member could accept blame for the killing. ${ }^{6}$

Sayyid Said sent a judge to the American Consulate to investigate the murder on his behalf. During this investigation the judge found no eyewitnesses to the murder, but turned to the evidence provided by the American Consul in which he provided details of the incident, including the 
confession of the American sailor. On the basis of this, the Omani judge determined that he could not punish the American sailor due to lack of evidence. Sayyid Said returned the case to Charles Ward, expecting that Ward would bear responsibility for producing the guilty sailor for punishment, or else make a restitution payment of $\$ 800.00$ to the family of the deceased, as was customary. However, Ward insisted that his first letter was in error and that no American had acknowledged guilt in the incident. Moreover, Ward allowed the sailors to return to their ship, and the Ann Perry set sail. 7

Because Ward failed to resolve the incident in accordance with Omani custom, the Sultan became angry and accused Ward of aiding and abetting the escape of the American sailors. The Sultan was convinced that Ward had ordered the ship out of port to circumvent Omani law, writing later to Ward: "You have sent the brig away and the whole ship." 8 However, Ward denied ordering the ship out of Zanzibar.

Ward reported on the Ann Parry. affair in a letter to Secretary of State Buchanan, including with it a letter from Sayyid Said to President Polk. In the latter, Said suggested that disputes between American citizens and Omani law be settled by treaty stipulation, and he requested of President Polk that the American government investigate the incident. 9 However, neither Ward's nor the Sultan's letters were answered, and the case was never settled. The Ann Parry. affair was left to lie dormant, promoting an ongoing strain in Omani-American relations. 10 


\section{INTERPRETING THE TREATY OF 1833}

The second important controversy to arise between Sayyid Said and Consul Charles Ward concerned the interpretation of the second article of the Omani-American Treaty of 1833 . This treaty had given American merchants the right to trade in any of the ports under the Sultan's control. In 1841, Richard Waters, America's first Consul in Zanzibar, had expressed to the Sultan the desire of American merchants to trade not only in the Sultan's ports, but throughout the coast. However, Sayyid Said refused. Additionally, the Sultan sent a letter to then President John Tyler requesting that he be given a letter from the president authorizing him to prevent American merchants from direct trading on the coast. Oddly, though, the Sultan did not send this letter through regular diplomatic channels, but instead sent it personally with Captain Andrew Ward (no relation to Consul Charles Ward), who was a trusted friend of Sayyid Said.

Meanwhile, Said sent four more letters to the President requesting a formal amendment of Article II of the Treaty of 1833, but the President did not respond. Said then asked Richard Waters to speak on his behalf when he returned to the United States. Waters had resigned his position as Consul at this time, and therefore asked the Sultan for full plenipotentiary powers to negotiate with the American Government on the issue. However, the Sultan rejected this idea. 11 Consequently, Waters left Zanzibar upon completion of his tenure as Consul without any formal solution to the conflict over the Treaty of 1833 .

The roots of this conflict originated in the years when officials first 
negotiated the Treaty of 1833. Article II of this treaty gave Americans the express right to purchase goods in any of the Sultan's ports. Trade expanded over the years, and by $1841 \mathrm{New}$ England merchants, supported by former Consul Richard P. Waters, expressed a desire to fully exploit the treaty's provisions. The issue focused on an area of the coast called the Mrima coast. Said's position was that the Mrima coast had not been visited by foreign traders, there was no precedent for trade there, and that there was not even a custom master in the port. On January 12, 1843, the U.S. State Department finally responded to Said's letters and formally surrendered its trading rights on the Mrima coast. American merchants would be advised to abide by the Sultan's wishes in that area.

The Sultan gave such great importance to this issue because he feared that direct trade on the coast by the Americans would encourage the British and French to demand the same right. Neither the British-Omani Treaty of 1839 nor the Franco-Omani Treaty of 1844 provided this right of access to trading on the coast. Furthermore, such direct trade would, the Sultan feared, undermine his economic and political power on the coast. 12 So when Charles Ward arrived to take up Waters' post, Sayyid Said renewed his campaign to amend Article II of the treaty, asking that Ward write a letter to his government requesting these changes. Further, he continued writing letters of his own to President Polk. However, the President failed to respond to Said's letters, and Ward also received no satisfactory responses.

The Sultan then changed tactics. He appealed to the British Foreign Minister Palmerston, requesting that the British government support his dispute with the United States over Article II. ${ }^{13}$ Lord Palmerston 
approached the Americans on behalf of Said, but the U.S. still refused to consider amendments to the treaty. However, in an effort to compromise, the U.S. acknowledged that it did not intend to press U.S. claims under Article II unduly. On June 15, 1848, Ward informed Said of the U.S. compromise, and Said accepted the American decision. The American government would not surrender its citizens' privileges granted under Article II, but at the same time it promised not to "open direct trade" on the coast. 14

One outcome of this dispute was the involvement of the British government in Omani-American relations. Ward wrote a letter to Secretary of State Buchanan complaining of interference on the part of the British Consul Hamerton in the treaty dispute. It had been Hamerton who had advised Sayyid Said to appeal to the British government in his dispute with the U.S. over Article II of the treaty. 15

\section{THE STATUS OF INDIAN NATIONALS}

The tenuous settlement of the controversy over the Treaty of $1833 \mathrm{did}$ not end the string of controversies between Ward and Sayyid Said. Another troublesome issue was that of Indian nationality, which had erupted in the wake of the "Bankruptcy Case" that Ward inherited from Waters upon taking up the latter's post in Zanzibar. The case involved two Indian nationals who owed debts to two American firms. When Ward first attempted to discuss the issue with Sayyid Said, he wished to clarify for technical reasons whose subjects these Indians were. The Sultan informed Ward that they were his subjects, but that he would intercede to help secure the claims of the American firms owed money. 16 The Sultan then ordered the liquidation of 
the Indians' property. After fifteen months of negotiations, Ward succeeded in securing seventy percent of the debt owed the two American firms. 17

The Bankruptcy Case is important because it once more divided the Americans and British on either side of the Sultan, just as had the issue of the treaty amendment. It was the position of Hamerton and the British government that Indians, as citizens of a British colony, were in fact British subjects. However, in accordance with a treaty signed in 1822 , the Indians were permitted to participate in the coast trade, as well as the slave trade, both of which were forbidden to the British as well as American merchants. 18 And this was the crux of the issue. If the Indians could be considered British subjects, Britain, by extension, would have a great trading advantage over the United States in the region. This is certainly part of the reason for Ward's siding with the Sultan against the British in the Bankruptcy Case.

Ward and Hamerton continued to debate the status of Indian nationality. For some time the Sultan considered the Indians to be his subjects, but in time he came to recognize them as British subjects. ${ }^{19} \mathrm{He}$ ultimately surrendered to Hamerton's and the British government's claims because the British were the dominant power in the Indian Ocean, and he needed their support and friendship to maintain his throne in the Gulf and East Africa. In explaining his decision to Ward, the Sultan told him that in the future whenever an Indian dealt with an American he would declare in writing his nationality (or allegiance, i.e., to Britain or Oman), and that this declaration would be binding. Ward had no choice but to accept the Sultan's decision, but he was unhappy with it. He wrote to the State Department that Hamerton's activities would destroy American interests in Zanzibar and East 
Africa and recommended that the United States government send a strong letter to Said. He also arranged for occasional visits to Zanzibar of U.S. warships. 20

The Indian nationality issue divided not just Ward and Said, but Ward and Hamerton as well. Ward fully believed that Hamerton's goal was to undermine America's position in the region and to actively harm relations between Oman and the United States. Whether or not Hamerton was the culprit, the result was that Omani-American relations never fully recovered under Ward's tenure as Consul at Zanzibar.

\section{THE FLAG DISPUTE AND WARD'S FINAL YEARS}

After the Indian nationality issue, disputes arose over even relatively trivial events. In 1850, Sayyid Said refused to fire a salute to the American flag on the Fourth of July, as was customary. Ward interpreted the Sultan's refusal as a direct insult to the American government and met with the Sultan to ask him why he'd refused the customary salute. ${ }^{21}$ The Sultan promised Ward that he'd provide the salute to the American flag, but reneged on the promise. When this happened, Ward again approached the Sultan and this time demanded a written apology and a twenty-one-gun salute. Said responded that the previous Consul, Waters, had always fired the first salute, and he insisted that the Americans must first fire their own salute. He refused to provide a written apology, but offered to refer the problem to the British and French Consuls. Ward refused the Sultan's offer and hauled down the American flag. 22

Soon after this Ward left Zanzibar for health reasons. He informed the 
Sultan in a letter that he was leaving the country and that he had appointed his Vice-Consul, William McMullan, to act in his absence. As final acts, Ward informed Secretary of State Clayton of his departure from Zanzibar and instructed McMullan not to raise the flag in Zanzibar. ${ }^{23}$ Ward's tenure in Zanzibar ended on this trivial note.

Upon returning to the United States, Ward once more wrote the Secretary of State about the flag dispute and recommended closing the American Consulate at Zanzibar. He felt that the Sultan had insulted the U.S. and that British Consul Hamerton was advising the Sultan in the dispute. He further advised that the U.S. should use force against Sayyid Said to secure American honor and respect. Because the Sultan saw only U.S. merchant vessels and not its warships, he could not appreciate the size and power of America. 24

On Ward's advice the U.S. dispatched John Aulick aboard the U.S.S. Susquehannah to Zanzibar. His mission was to maintain American dignity and honor, although he was specifically instructed not to humiliate the Sultan or his people. The American warship arrived at Zanzibar on December 2, 1851, with Aulick carrying a cordial letter to Said from President Fillmore. 25 At this time, however, Sayyid Said was away from Zanzibar (he'd returned to Muscat) and had left his son, Khalid, in charge.

Aulick called a meeting of American merchants in Zanzibar to discuss the flag dispute and their commercial position in Zanzibar. Although the American merchants had supported Ward in the flag dispute, they also believed Said was incapable of insulting the American flag or American honor, and they regarded the July 4th dispute as a misunderstanding. "His 
Highness considers us first among foreign merchants here and we have no desires for any greater favors than we have received," wrote one American merchant to Aulick regarding their special relationship. 26

Aulick met with Khalid to discuss Omani-American relations in light of the July 4th incident. Khalid welcomed Aulick and assured him the incident would not damage the relationship between America and Oman. "We want what is best for both parties, and together we agree that the friendship between America and the Arab nations is an old friendship," Khalid told him. 27 The outcome of this successful meeting was that Khalid and Aulick agreed to settle the Flag dispute. Khalid would fire a salute to the American Flag and the Americans would return it. The dispute finally settled, the American Flag was once more raised in Zanzibar. Aulick and Khalid celebrated this victory of rapprochement with a state dinner, and, his mission completed, John Aulick departed Zanzibar with friendly relations restored. 28

Despite this amicable settlement of the flag dispute, Ward's term in Zanzibar had been stormy and his several disputes with Sayyid Said had affected Omani-American relations greatly. Ward's policies could only lead to the Sultan's being alienated and driven away from the United States, and toward the British. 29

\section{THE WILLIAM McMULLAN YEARS AND THE DEATH OF SAID, 1852-1856}

It was in this strained diplomatic climate that in 1852 William McMullan took over as the third American Consul in Zanzibar. McMullan had resided in Zanzibar for some years as an agent of the trading firm of 
Shepard and Bertram. His background, then, was in international trade. He was born on March 31, 1826, in Salem, and at 26 years old was the youngest Consul ever appointed to the position. McMullan served his youth in the Salem post office and spent some of his early years in East India. He had served as Vice Consul under Ward and as acting Consul during most of $1851 .{ }^{30}$ His experience in Zanzibar trade as a result of these positions gained the respect of the local population. Sayyid Said was pleased to receive McMullan and hoped to continue friendly Omani-American relations.

Despite the diplomatic reverses of the Ward years, the commercial activity of Americans in Zanzibar continued. In fact, American merchants were still the most prominent Western traders in the region. However, between 1845-1856 they faced increasing competition, both foreign and domestic.

American trade in the region was led by two Salem firms, Pingree and West and Shepard and Bertram. These two had competed since Waters, who was an agent of of Pingree and West, assumed his position as Consul in Zanzibar. Upon leaving Zanzibar in 1850, Charles Ward became an agent for the firm of Shepard and Bertram, and gave that firm a similar inside advantage in the Zanzibar trade. These two Salem firms tried to corner their market and prevent other American firms from entering the Zanzibar trade. Despite their tactics, however, other firms from Boston and Providence, Rhode Island, entered the market and provided new competition. In 1852, Rufus Green and Company of Providence established an agent in Zanzibar and quickly became a powerful competitor. ${ }^{31}$ Healthy competition led to increases in the prices paid for goods, and consequently a reduction in profit. 
This forced merchants to extend their activities to Eastern African and Arabian ports. 32 This is precisely the development that Sayyid Said had feared when he sought an amendment to Article II of the Treaty of 1833.

However, the real threat to American dominance did not come from American competitors, but from the Europeans, whose commercial influence in the region expanded greatly throughout the 1840 s and 1850 s. In 1849 , the influential Hamburg firm of Wilhelm O'swald and Company opened an agency in Zanzibar, and soon after the Germans became increasingly powerful in the Zanzibar market. 33 Not just the Germans, but also the French entered the Zanzibar market. In 1844, the French signed a treaty with the Sultan which expanded France's trade with Said's territories. In 1849, Sayyid Said sent his own vessels to trade in Marseilles, and two years later, firms Vidal Bros. and Rabaud Bros, prominent Marseilles merchants, were established in Zanzibar. In 1854, another powerful Marseilles firm, Regis Bros., joined the Zanzibar trade. ${ }^{34}$ English merchants, on the other hand, although they traded in Zanzibar for many years, could not compete with America's superior goods. There were no British businesses established in Zanzibar, and the only Briton living there was the Consul. 35 The British Consul's main objective was to establish political influence.

American trade managed to meet the European challenge and hold on to its leading position in the Zanzibar trade. American cotton, in heavy demand in East Africa and Arabia, was of excellent, durable quality. The native name for this cotton cloth was "merikane," a word still used today.

Omani-American relations continued throughout this period through both diplomatic and commercial channels. Diplomatically, McMullan's term 
was uneventful, to everyone's relief, and American merchants continued to compete with Europe throughout Zanzibar and East Africa. Unfortunately for the merchants, however, Said became more involved politically with his territories and was drawn increasingly closer to the British camp.

For many years Said tried to remain free of British influence but, because he had to maintain his position in Oman and protect his territorial possessions, he was forced to deal with this most potent political and military power in the region. His position in Oman and East Africa was in jeopardy on two fronts: from the domestic conservative Ibadi unrest and, on the north, from the Wahabbi threat. Furthermore, the Persians were attacking Bandar Abbas, an area of Persia earlier annexed by Said. Consequently, Said's last years involved trying to keep the Tbadi conservatives within his rule, diminish the Wahabbi threat, and protect Bandar Abbas from invasion. 36 Said succeeded in settling these problems but he continued to worry about French activities in East Africa; France had acquired the Cumoro Islands in 1843.

In the final years of his reign, Sayyid Said faced challenges which increased his dependence on Britain. Said's long life had become a struggle at the end. He became tired of the endless internal disputes and the constant threat from the Wahabbi. He tried throughout to maintain his independence, which is what induced him to court American commercial investment in his country, but his attempts to create a balance of outside influences was not entirely successful. Britain became so strong and powerful a force throughout the region, holding all of India and controlling the primary trade routes through the near and far east. In 1839 Britain occupied Aden, having signed 
a general peace treaty with the rulers of the Trucial Coast in 1820.37

In fact, the British clearly intended to take Said's territory after he died. Charles Ward asserts as much in a letter: "From what I have heard, and from the many conversations that I have had with the British consul, it appears to me that it is the policy of the British government to take possession of the East Coast of Africa at no distant day." 38 Said's policies of balancing the commercial powers and interests in his territories with intelligent treaty forming helped to put off this British desire for his lands, however, and it would be some time before the British would have their way in East Africa. Despite Said's efforts, though, the British assumed a Protectorate over Zanzibar in 1890, and on March 20, 1891, Britain signed an agreement in which the Sultan of Oman agreed "never to cede, to sell, or to mortgage to any other governments [Omani territory] without the knowledge of the British government."39

Ultimately, then, Said's reign was not to last. On September 15, 1856, Said left Muscat to return to Zanzibar. Before leaving he bid his mother good bye in the following terms: "Goodbye, Mother. I do not think we shall meet again in this world. I have a feeling this is my last voyage, so I am taking my death shroud with me so that death may not come on me unprepared., $\mathbf{4 0}$

Soon after departing Muscat, Said began to suffer pains in his legs and shortly after suffered an attack of dysentery. On October 19, 1856, Said died at the age of sixty-seven. Six days later, his ship arrived in Zanzibar to a crowd of people awaiting his arrival.

On October 2, 1855, McMullan left Zanzibar and embarked on the Iosco for Salem. He resigned as consul in 1856, the year of Said's death. McMullan 
was succeeded by his vice consul, Daniel H. Mansfield. In November of 1856, Mansfield wrote to his government and informed them of Said's death, and included a letter from Majid to President Pierce in which he declared himself Sultan of Zanzibar and the East African possessions. President Pierce responded with a letter expressing his sincerest condolences. 41

Said's death ended an era marked by the establishment of a remarkable commercial empire. Thereafter, Oman and Zanzibar were divided between Said's two sons, Majid and Thuwainy. Majid declared himself Sultan of Zanzibar and East Africa, while Thuwainy claimed the right to succeed the sovereignty of his father in Oman and Zanzibar. Their dual claims to the rulership of Zanzibar created a serious crisis, and Thuwainy threatened to use force if necessary. Lord Canning, British Governor-General of India, intervened to settle the disputes between Said's sons, successfully dividing Said's Empire between Majid and Thuwainy. Majid was to rule Zanzibar and would make an annual payment of 40,000 Maria Theresa dollars to Oman. Thuwainy was given Oman. Unfortunately, the division of Said's Empire between his two sons resulted in the rapid decline of both Oman and Zanzibar. ${ }^{42}$

Sayyid Said ruled Oman and Zanzibar for fifty years. He was the first ruler to encourage American trade and promote the economic development of Zanzibar and East Africa. Since his first visit to Zanzibar in 1828, and his first meeting with Edmond Robert, Omani-American commercial and diplomatic relations reached an impressive peak. American consuls and merchants, with the exception of Ward, praised him. He laid a solid foundation for future relations between the United States and the Gulf 
region, opening the door to American relations with the region.

\section{CONCLUSION}

Omani-American commercial and diplomatic relations in the nineteenth century were the outgrowth of the personal and commercial interests of the two countries as promulgated by Sayyid Said and Edmund Roberts, who might be considered the father of the Omani-American Treaty of 1833. Roberts, a merchant trader, opened for the American merchant fleet a long-standing and lucrative port of call in the Arabian Gulf, the first such port in the region. This first treaty between a Western power and one of the Gulf states also served as a model for subsequent treaties between the Sultanate of Oman and other European countries. Although certain political concerns may have formed a backdrop to these negotiations for some of the European countries (particularly the British), and although Sayyid Said had some desire to realize a military advantage out of his alignment with the U.S., the fact remains that the primary motivation on all parts for the opening of the ports of Oman to American, and subsequently European traders, was commercial development.

Because some American merchant traders, particularly those sailing out of Salem, Massachusetts, were unable to compete very effectively with merchants out of Boston and New York in the Far East trade, they were interested in opening trade lines to Zanzibar as a lucrative alternative. America's first consul to Zanzibar, Richard P. Waters, was in fact from a Salem trading family, and in addition to serving as a representative in Zanzibar for the American Government, he was equally, if not more so, a 
representative of Salem trading interests. He devoted his time in Zanzibar to these commercial interests, and also established for himself a lucrative arrangement in partnership with Zanzibar's master of the custom house, Jairam Sewji. Regardless of the extent to which Waters may have abused his official position in the furtherance of his own and Salem merchants' commercial interests, Waters' tenure as consul to Zanzibar was most productive for both countries' political and commercial goals. In Waters' defense, however, it might be said that his conduct and ethics were those of his times, during which consuls were not paid by the federal government, but were expected to support themselves by commercial activities conducted in conjunction with their consular duties.

Omani-American relations expanded and prospered during Waters' tenure in Zanzibar. When he was succeeded by the second American Consul, Charles Ward, in 1846, the situation changed significantly. Although Ward, like Waters, was a New England merchant, his diplomatic skills were significantly weaker. His tenure as consul was marked by one dispute after another, and it culminated in the breaking off of diplomatic relations between America and Oman in 1850. The damaged relations were repaired in 1851 in a special mission headed by John Aulick, but the damage Ward succeeded in doing was in part irreversible. During Ward's tenure, the British took advantage of deteriorating American influence, even promoted it, and installed themselves as prominent competitors with the American merchants. Soon to follow were the French and Germans, all of them eventually signing commercial treaties on the model of the American treaty.

Ward resigned his post in 1852 and was replaced by William 
McMullan, the third American Consul to Zanzibar. McMullan, like his predecessors, also had strong ties to the Salem merchant traders, and under his tenure Omani-American commercial and political relations expanded and developed, despite the fact that the Salem hegemony that existed in the Waters years was over and never to be reclaimed. Zanzibar was a well developed port of call by this time, and the Salem merchants were forced to compete not just with the British and French, but with Boston and New York merchants as well.

This was the period during which Omani-American relations matured. Sayyid Said welcomed the American presence for both political and commercial reasons. Unlike the British and French, the Americans did not meddle in the Sultan's internal affairs, as they had no significant vested political or military interests in the region. Said therefore enjoyed the American presence because it acted as a balance against the British and French. Focal in Said's struggle with the British was the latter's intervention to suppress the slave trade, which had been rife off the East African coast. Treaties dating back to 1822 , and including treaties signed in 1839 and 1845, had been signed with the British to control the export of slaves from the Sultan's African to his Asian territories, and the pressure had forced Said to restructure his country's economic profile. The void left by suspension of the slave trade was conveniently filled by the growing American merchant trade.

Western trade enabled Sayyid Said to increase his wealth and extend his political and economic control over the East African coast. Through the appointment of regional governors and customs agents he controlled the movement of goods from East Africa, and his caravans traded regularly with 
the African interior. He also developed his own merchant fleet and his vessels sailed regularly to India, France, and Britain. His famous vessel Sultanah even visited New York in 1840 on a diplomatic mission, the first visit of an Arab vessel to the United States.

The relationship between the United States and Sayyid Said was mutually beneficial. The interests of each complemented the other's. Both the Salem merchants and Sayyid Said prospered. The harmony of the relationship (disregarding the unfortunate years of Charles Ward) was due largely to the farsighted and competent leadership of Sayyid Said. When Said at last died, in 1856, the years of prosperity came to an end. A bitter battle for succession to Said's crown waged by his two sons, Majid and Thuwainy, resulted in the division of the Sultanate. Oman and Zanzibar were politically and economically divided, which led to the speedy decline of both. This division suited the political and military interests of the British, whose colonial empire straddled the Middle East, but it marked the end of an illustrious chapter in the history of the region.

In April, 1983, Sultan Qaboos bin Said Al-Said of Oman visited Washington to meet with President Reagan to mark the 150th anniversary of the historic signing of the Treaty of Amity and Commerce of 1833 between the United States and Oman. The event was a testimonial to OmaniAmerican relations, which are a model of the desire on the part of two peoples for mutual interest and respect, and was a memorial to the wisdom of the framers of the relationship, Edmund Roberts, Richard Waters, and particularly Sayyid Said. 


\section{ENDNOTES}

1 Ward, Charles. "Biographical Sketch, 1816-1876," in Ward Ms, no. 47. Salem: Essex Institute, p. 2.

2 Sultan Said to President Polk, February 24, 1846, National Archives, Vol. II.

3 Gray, Sir John. History of Zanzibar from the Middle Ages to 1856, Oxford: Oxford Univ. Press, 1962, p. 214. Brady, C.T. Commerce and Conquest in East Africa, with Particular Reference to Salem's Trade with Zanzibar, Salem: 1950, p. 108.

4 First Mate of the Ann Perry to C. Ward, September 4, 1846, in Ward Ms., Salem: Essex Institute.

5 Ward to Said bin Sultan, August 31, 1846, in Ward Ms, Salem: Essex Institute. Gray, pp. 214-215.

6 Ward to Buchanan, September 14, 1846, National Archives, Vol. II.

7 Tbid.

8 Ibid.

9 Said to President Polk, August 9, 1846. National Archives, Vol. II.

10 Gray, History of Zanzibar, p. 216.

11 Said to Waters, February 3, 1845, Waters Ms. Box 7, P.M., Salem.

12 Nicholls, C.S. The Swahili Coast, pp. 313-314.

13 Gray, History of Zanzibar, p. 219.

14 Gray, History of Zanzibar, pp. 220-221.

15 Ward to Buchanan, March 21, 1847, National Archives, Vol. II. 16 Bennett, "Americans in Zanzibar, 1845-1865," p. 33. 
17 Ward to Buchanan, March 7, 1847, National Archives, Vol. II. Bennett, p. 34.

18 Nicholls, p. 223.

19 Ward to Buchanan, March 13, 1847, National Archives, Vol. II.

20 Ibid.

21 Ward to Said, July 5, 1850, Ward Ms., Vol. A.

22 Said to Ward, July $5 \& 6,1850$, Ward Ms, Vol. A. Ward to Said, July 8 , 1850 , Ward Ms., Vol. A.

23 Ward to Said, September 2, 1850, Ward Ms. Ward to Clayton, September 4, 1850, National Archives, Vol. III.

24 Nicholls, p. 195. Abbot to Webster, March, 1851, National Archives, Vol. III.

25 Coupland, East Africa and Its Invaders, p. 381.

26 Webb, Jelly and Mosuney to Aulick, December 15, 1851, National Archives, Vol. III.

27 Khalid to Aulick, December 6, 1851, National Archives, Vol. III.

28 Aulick to Webster, December 8, 1851, National Archives, Vol. III.

29 Bennett, "Americans in Zanzibar, 1845-1865," p. 51

30 Ward, Charles. Biographical Sketch, Salem: Essex Institute, p. 2.

31 Nicholls, p. 329.

32 Duignan and Gann, p. 76.

33 Coupland, East Africa and Its Invaders, pp. 322-323.

34 Nicholls, p. 339.

35 Coupland, East Africa and Its Invaders, p. 491. 
36 Al-Maamiry, Ahmed. Omani Sultans in Zanzibar, 1832-1964, New Dehli: Lancers Books, 1988, p. 10. Kelly, J.B. Britain and the Persian Gulf, 17951880 , p. 530. Wilkinson, John C. The Imamate Tradition of Oman, London: Cambridge Univ. Press, 1987, pp. 227-228.

37 Waterfield, Gordon. The Sultans of Aden, London: John Murray, 1968, pp. 70-100. Hawley, Donald. The Trucial States, London: George Allen, 1971, pp. 126-141.

38 Ward, March 13, 1851, National Archives, Vol. III. Nicholls, p. 196.

39 Kelly, p. 835.

40 Quoted in Al-Maamiry, p. 11.

41 Mansfield to Marcy, November 23, 1856, National Archives, Vol. III.

42 Al-Maamiry, p. 14. 


\section{SELECTED BIBLIOGRAPHY}

\section{Archival Sources}

\section{MIDDLE EAST/ASIA}

Cultural Foundation Center for Documentation and Research. Abu Dhabi, United Arab Emirates.

Contains collections of American and European historical archives. Of particular interest are collections of letters of Edmund Roberts to the U.S. State Department contained in the American Archives Section, cataloged under "Records of the Department of State Communications from Special Agents" (cited as "Special Agents" in the bibliography), Volume X, February 1, 1832, through March 4, 1837.

Ministry of National Heritage and Culture, Documentary Section. Muscat, Oman.

Contains collections of the Zanzibar Archives, including "Letters From Hamerton to Said," as well as from several British merchants to both Hamerton and Sayyid Said. These letters are translated into Arabic.

\section{UNITED STATES}

Essex Institute. Salem, Massachusetts.

Contains the largest and among the most valuable collections of business papers from nineteenth century merchant trading families. These are perhaps the most important source of data on U.S.-Omani trade relations in Zanzibar in the nineteenth century. Also collected are ships' logs and personal journals of crew members. Includes the "Papers of R. P. Waters," which includes letters in Arabic and lists of foreign vessels calling at Zanzibar in the years 1832-1837. Also included are the "Papers of C. Ward," the second American consul to Zanzibar, a large collection of documents covering American-Omani relations in the years 1846-1852.

National Archives, Washington D.C.

Contains "Dispatches from United States Consuls in Zanzibar, 18361906 " (M-468 [5 rolls] and T-638 [2 rolls]). This selection contains American consular correspondence from Zanzibar. Also contains "Reports from Special Agents to the State Department" (Microfilm 37, Roll 10), which includes letters from Edmund Roberts to the State Department. 
Peabody Museum. Salem, Massachusetts.

Contains a large collection of documents from various American consulates as well as the records of merchants involved in trade with Zanzibar and Muscat. Included are papers of R.P. Waters (1836-1847), in a section entitled "Journals, Notes, and Letters." The papers describe Waters' business affairs at Zanzibar as well as containing letters in Arabic from Sayyid Said.

Publications of the United States Government. Washington, D.C. for (1) Journal of the Senate of the United States of America (24th Congress, 2nd Session, 1836); and (2) Journal of the House of Representatives of the United States of America (26th Congress, 1st Session, 1840).

\section{LONDON}

India Office Library and Records. London.

Contains copies of correspondence from British Consul Hamerton to the British Foreign Office (IOR R/15/106), as well as copies of the AmericanOmani Treaty of 1833 (IOR R/15/1/409). Contains manuscripts from Hamerton's tenure as British consul at Zanzibar (1840-1857) (IOR E/4/1072). (1840-1857) (IOR E/4/1072).

\section{Books and Articles}

Abu-Yassin, Samir M. Ali. Omani-British Relations, 1798-1856 (in Arabic). Arabian Gulf Studies Center Publication. Basrah: Basrah University, 1981.

Al-Baharna, Husain. The Arabian Gulf States: Their Legal and Political Status and Their International Problems. Beirut: Librairie Duliban, 1975.

Al-Farsi, Ali Abdullah. Omani-Persian Relations during Al Bu-Said's State 1741-1871 (in Arabic). Alexandria, Egypt: Univ. of Alexandria, 1984.

Al-Maamiry, Ahmed H. Oman and the Coast of Africa. New Delhi: Lancer's Books, 1985. Books, 1988. Omani Sultans in Zanzibar, 1832-1964. New Delhi: Lancer's

Al-Mughiri, Said Bin Ali. Jahinah Al-akhbar Fi Tarikh Zanjabar (in Arabic). Abdullah Amir (ed.). Muscat: Ministry of National Heritage and Culture, 1979. 
Al-Naqar, Omar. "Arabic Materials in the Government Archives of Zanzibar" History in Africa, vol. V (1978). 377-382.

Al-Qasimi, Sultan Mohammed. The Myth of Arab Piracy in the Gulf. New Hampshire: Croom Helm, 1985.

Allen, Calvin H., Jr. Oman: the Modernization of the Sultanate. Boulder, Colorado: Westview Press, 1987.

Bailey, Thomas A. A Diplomatic History of the American People, 10th ed. Englewood Cliffs, NJ: Prentice-Hall, 1970.

Beachey, R.W. The Slave Trade of Eastern Africa. New York: Harper \& Row, 1976.

Bemis, Samuel F. A Diplomatic History of the United States, 3rd ed. New York: Henry Holt, 1950.

Bennett, Norman R. “Americans in Zanzibar: 1825-1845.” Essex Institute Historical Collections, vol. XCV, no. 3 (July, 1959). Salem: Essex Institute. 239-262.

. “Americans in Zanzibar: 1845-1865." Essex Institute Historical Collections, vol. XCVII, no. 3 (July, 1961). Salem: Essex Institute. 31-56.

. “Americans in Zanzibar: 1865-1915." Essex Institute Historical Collections, vol. XCVIII, no. 3 (July, 1962). Salem: Essex Institute. 3661.

.William H. Hawthorne: Merchant and Consul in Zanzibar." Essex Institute Historical Collections, vol. XCIX, no. 1 (January, 1963). Salem: Essex Institute. 117-146.

“France and Zanzibar: 1844-1860s." International Journal of African Historical Studies (two parts), vols. 6 (1973) 602-632 and 7 (1974) 27-55.

. Africa and Europe, from Roman Times to National

Independence, 2nd ed. New York: African Pub. Co., 1984.

1984.

. The Arab State of Zanzibar: A Bibliography. Boston: G.K. Hall,

Bennett, Norman R. and G.E. Brooks (eds.). New England and Merchants in Africa: A History Through Documents, 1802-1865. Boston: Boston Univ. Press, 1965. 
Berman, Edward H. "Salem and Zanzibar, 1825-1850: Twenty-Five Years of Commercial Relations." Essex Institute Historical Collections, vol. CV (October, 1969). Salem: Essex Institute. 338-39.

Bevans, Charles I. (ed.). Treaties and Other International Agreements of the United States of America, 1776-1949, vol XII. Department of State Publication. Washington: GPO, 1974.

Bidwell, Robin. "Bibliographical Notes on European Accounts of Muscat: 1500-1900.” Arabian Studies, vol. 4. 1978. 123-159.

1978.

- A History of the Arab State of Zanzibar. London: Methuen,

Brady, Cyrus T. Commerce and Conquest in East Africa, With Particular Reference to the Salem Trade with Zanzibar. Salem: Essex Institute, 1950.

Briton, C.P. Britain and the Persian Gulf: 1894-1914. Berkeley: Univ. of California Press, 1967.

Browne, John Ross. Etchings of a Whaling Cruise (John Seelye, ed.) Boston: Harvard Univ. Press, 1968.

Burton, R.F. Zanzibar: City. Island and Coast. 2 vols. London: Tinsley, 1872.

Cooper, F. Plantation Slavery on the East Coast of Africa. New Haven: Yale Univ. Press, 1977.

Coupland, Sir Reginald. East Africa and Its Invaders, From Earliest Times to the Death of Sayvid Said in 1856. New York: Russell \& Russell, 1965.

. The Exploitation of East Africa, 1856-1890: The Slave Trade and the Scramble. Evanston: Northwestern Univ. Press, 1967.

Duignan, Peter and L. H. Ganan. The United States and Africa: A History. Cambridge: Cambridge Univ. Press, 1984.

Duignan, Peter and Clarence Clendenen. Americans in Black Africa up to 1865. Stanford: Stanford Univ. Press, 1964.

Eilts, Hermann F. "Ahmad bin Na'aman's Mission to the United States in 1840: The Voyage of Al-Sultanah to New York City." Essex Institute Historical Collections, vol. XCVIII, no. 4 (October, 1962). Salem: Essex Institute. 31-56.

The United States and Oman: 150 Years of Friendship. Muscat, Oman: Ministry of National Heritage and Culture, 1985. 
Edmund Q. Roberts, 1784-1836: A Diplomatic and Personal

Memoir. Unpublished book manuscript, 1989.

Fairburn, William A. Merchant Sail, Center Lofell: Fairburn Marine Educational Foundation, 1947.

Freeman-Grenville, G.S.P. "Some Problems of East African Coinage.” Tanganvika Notes and Records, no. 52 (October, 1959). 250-260.

. "The Historiography of the East African Coast." Tanganyika Notes and Records, no. 55 (September, 1960). 279-289.

, (ed.). The East African Coast: Selected Documents. Oxford:

Clarendon Press, 1962.

Gates-Hunt, Richard H. "Salem and Zanzibar: A Special Relationship." Essex Institute Historical Collections, vol. CXVII, (January, 1981). Salem: Essex Institute. 1-26.

Graham, Gerald. Great Britain in the Indian Ocean: A Study of Maritime Enterprise, 1810-1850. London: Oxford Univ. Press, 1967.

Gray, John. "Early Connections Between the United States and East Africa." Tanganyika Notes and Records, no. 22 (December, 1946). 55-86.

History of Zanzibar. From the Middle Ages to 1856. London: Oxford Univ. Press, 1967.

Gregory, Robert G. India and East Africa: A History of Race Relations Within the British Empire, 1890-1939. Oxford: Clarendon Press, 1971.

Graz, Liesl. The Omanis, Sentinels of the Gulf. London: Longman Group, Ltd., 1982.

Haight, Mabel V. Jackson. European Powers and Southeast Africa: A Study of International Relations on the Southeast Coast of Africa, 1796-1856. London: Routledge and Kegan Paul, 1967.

Harraz, Rajab. East Africa and European Colonization (in Arabic). Cairo: Arabian Renaissance House, 1968.

. The Ottoman State and the Arabian Peninsula, 1840-1909 (in Arabic). Cairo: Arabian Research and Studies Center, 1970.

. East Africa and Britain from Colonization to Independence (in Arabic). Cairo: Studies and Research Center, 1971. 
Hart, C. "Extracts from Brief Notes of a Visit to Zanzibar." (Selections from the records of the Bombay government, vol. XXIV, 1856.) In T.R. Huges (ed.), Arabian Gulf Intelligence, New York: Oleander Press, 1985.

Hawley, Donald. Oman and Its Renaissance. London: Stacey International, 1977.

. The Trucial States. London: Allen and Unwin, 1970.

Hickman, G.M., and W.H.G. Dickins. The Lands and People of East Africa. London: Longman Group, 1973.

Hollingsworth, Lawrence W. A Short History of East Africa. London: McMillan, 1951.

McMillan, 1953.

. Zanzibar Under the Foreign Office, 1890-1913. London:

. The Asians of East Africa. London: McMillan, 1960.

Holmes, C.F. “Zanzibar's Influence at the Southern End of Lake Victoria: The Lake Route." African Historicall Studies, vol. IV, no. 3, 1971. 477-503.

Howard, Lawrence C. "American Involvement in Africa South of the Sahara, 1800-1860.” Dissertation. Harvard Univ., 1956.

Hurewitz, J.C. (ed.). Diplomacy in the Near and the Middle East: A Documentary Record, 1535-1914. Vol. 1. Princeton: Princeton Univ. Press, 1956.

Ingham, Kenneth. A History of East Africa (3rd ed.). New York: Frederick \& Praeger, 1965.

Ingrams, William. Zanzibar: Its History and Its People. London: Cass, 1967.

Irwin, Wallace. America in the World: A Guide to U.S. Foreign Policy. New York: Foreign Policy Association, 1983.

James, W.F. “Gun Running in Arabia: The Introduction of Modern Arms to the Peninsula, 1880-1914.” Thesis. Portland State Univ., 1989.

Kelly, J.B. Britain and the Persian Gulf, 1795-1880. Oxford: Clarendon Press, 1968.

Kingsnorth, G.W. and Zoe Marsh. An Introduction to the History of East Africa. London: Cambridge Univ. Press, 1960.

Kirby, C.P. East Africa. New York: David White, 1968. 
Krapf, J.L. Travels. Researches and Missionary Labours in Eastern Africa. London: Trubner \& Co., 1860.

Kumar, R. India and the Persian Gulf Region. London: Asia Publishing House, 1965.

Landen, Robert G. Oman Since 1865: Disruptive Modernization in a Traditional Society. Princeton: Princeton Univ Press, 1967.

Lofchie, Michael F. Zanzibar: Background to Revolution. Princeton: Princeton Univ. Press, 1965.

Lorimer, J.G. Gazetteer of the Persian Gulf (6 vols.). Farnborough, England: Gregg, 1970.

Lyne, R.N. Zanzibar in Contemporary Times. London: Hurst and Blackett, 1965.

Mallory, Lowry. “American-East African Relations, 1827-1861.” Dissertation. Texas Christian Univ., 1976.

Mangat, J.S. A History of Asians in East Africa. London: Oxford Univ. Press, 1969.

Maurizi V. (Shaikh Mansur). History of Seyd Said (in Arabic). 1819.

Translation by Fadhal Mahumud, Beriut: Arabian Study Press: 1988.

McCall, Daniel F., Norman R. Bennett and Jeffrey Butler (eds.). Eastern African History. New York: Praeger, 1969.

McEwan, P.J.M. (ed.). Nineteenth Century Africa. London: Oxford Univ. Press, 1969.

Middleton, J. and Jane Campbell. Zanzibar, Its Society and Its Politics. London: Oxford Univ. Press, 1965.

Miller, H. (ed.). Treaties and Other International Acts, vol. 3 "The United States of America." Washington: GPO, 1933.

Miles, S.B. The Countries and Tribes of the Persian Gulf. 2 vols. 1919 (2nd ed.) London: Frank Cass, 1966.

Morison, S.E. A Maritime History of Massachusetts: 1783-1860. Boston: Houghton Mifflin, 1931.

Mughiri, S.A. Juhaynat al-Akhabar fi Tarikh Zanjibar. (A. Amar, ed.) Muscat: Ministry of National Heritage and Culture, 1979. 
Nicholls, C.S. The Swahili Coast: Politics. Diplomacy, and Trade on the African Coast. 1798-1856. London: Allen \& Unwind, 1971.

Northway, Philip E. "Salem and the Zanzibar-East African Trade, 18251845." Essex Institute Historical Collections, vol. XV, no. 2 (April) 1954. Salem: Essex Institute. 123-153.

. "Salem and the Zanzibar-East African Trade, 1825-1845." Essex Institute Historical Collections, vol. XV, no. 3 (July) 1954. Salem: Essex Institute. 261-273.

. "Salem and the Zanzibar-East African Trade, 1825-1845."

Essex Institute Historical Collections, vol. XV, no. 4 (October) 1954. Salem: Essex Institute. 361-388.

Nwulia, Moses D. Britain and Slavery in East Africa. Washington: Three Continents Press, 1975.

Ochsenwald, William. Religion. Society, and the State in Arabia: The Hijaz Under Ottoman Control, 1840-1909. Columbus: Ohio State Univ. Press, 1984.

Oliver, Roland, and Anthony Atmore. Africa Since 1800. London: Cambridge Univ. Press, 1967.

Oliver, Roland, and Matthew Gervase (eds.). History of East Africa vol. 1. London: Oxford Univ. Press, 1963.

Oliver, Roland, and J.D. Fage (eds.). The Cambridge History of Africa, vol 5, "From 1790-1870." London: Cambridge Univ. Press, 1976.

Osgood, J.B.F. Notes of Travel and Recollections of Majungo, Zanzibar, Muscat, Aden. Mocha, and Other Eastern Ports. Salem: Greamer, 1854.

Paulin, Charles O. Diplomatic Negotiations of American Naval Officers, 1778 1883. Baltimore: Johns Hopkins Univ. Press, 1912.

Pearce, Francis B. Zanzibar: The Island Metropolis of Eastern Africa. London: Frank Cass \& Co., 1967.

Peterson, J.E. Oman in the Twentieth Century. London: Croom Helm, 1978.

Phillips, James D. Salem and the Indies. Boston: Houghton Mifflin, 1947.

Putnam, George B. "Salem Vessels and Their Voyages." Essex Institute

Historical Collections, vols. LVII-LXVI, Salem: Essex Institute. 19211930. 
Qasim, Jamal Zakariyya. Zanzibar (in Arabic). Cairo: Anglo-Egyptian Library, 1959.

Press, 1966.

. Arabian Gulf, 1840-1914 (in Arabic). Cairo: Ain Shams Univ.

. Dawlah Bu Said in Oman and East Africa, 1741-1861 (in

Arabic). Cairo: Modern Cairo Library, 1968.

. "Oman State in East Africa," (in Arabic). In Seminar for Omani

Studies, vol. 3. Muscat: Ministry of Heritage and Culture, 1980. 75-136.

Risso, Patricia. Oman and Muscat: An Early Modern History. New York: St. Martin's Press, 1985.

.Muslim Identity in Maritime Trade: General Observations and Some Evidence From the 18th Century Persian Gulf/Indian Ocean Region." Middle East Studies, vol. 21, 1989. 381-392.

Roberts, Edmund. Embassy to the Eastern Courts of Cochin-China. Siam and Muscat. Wilmington: Scholarly Resources, 1972.

Ruschenberger, W.A. Narrative of a Vovage Round the World. Including an Embassy to Muscat and Siam in 1835, 1836, and 1837. Philadelphia: Carey, Lea \& Blanchard, 1838.

Salil, Razik. History of the Imams and Sayyids of Oman from A.D. 661 to 1856. Trans. by George P. Badger. London: Hakluyt Society, 1871.

Sanger, R.H. The Arabian Peninsula. Ithica: Cornell Univ. Press, 1954.

Sheriff, A.M.H. "The Rise of a Commercial Empire: An Aspect of the Economic History of Zanzibar, 1770-1873.” Dissertation, Univ. of London, 1971.

. Slaves. Spices and Ivory in Zanzibar: Integration of an East African Commercial Empire into the World Economy, 1770-1873. Athens: Ohio Univ. Press, 1987.

Smith, E.T. "Early Records of the Consulate at Zanzibar." American Foreign Service Journal, vol. XVII (May) 1940. 266-273.

Speece, Mark. "Aspects of Economic Dualism in Oman, 1830-1930."

International Journal of Middle East Studies, vol. XXI, 1989. 495-515.

Stuart, Graham. American Diplomatic and Consular Practice, 2nd ed. New York: Appleton-Century-Crofts, 1952. 
Thomas, B. "Rule Under the Al Bu-Said Dynast of Oman, 1741-1937." Proceedings of the British Academy, vol. XXIV, 1938. 27-53.

Toomey, M. Ethelbert. "The Negotiation of the Anglo-American Zanzibar Coventions of 1902, 1903, and 1905." Thesis. Fordham Univ., 1954.

Waterfield, Gordon. The Sultans of Aden. London: John Murray, 1968.

Waters, Richard. "Richard Palmer Waters: A Biographical Sketch.” Bulletin of the Essex Institute, vol XX, 1888. 174-183.

Were, Gideons, and Derek A. Wilson. East Africa Through a Thousand Years: A History of the Years A.D. 1000 to the Present Day. New York: Africana Pub. Corp., 1971.

Wilkinson, John C. The Imamate Tradition of Oman. London: Cambridge Univ. Press, 1987.

Winder, R. Bayly. Saudi Arabia in the Nineteenth Century. New York: St. Martin's Press, 1965.

Wristen, Henry M. Executive Agents in American Foreign Relations. Gloucester: Peter Smith, 1967. 